\title{
The role of natural killer cells in liver inflammation
}

\author{
A. J. Highton ${ }^{1}$ - I. S. Schuster ${ }^{2,3} \cdot$ M. A. Degli-Esposti ${ }^{2,3} \cdot$ M. Altfeld $^{4}$ (I)
}

Received: 10 March 2021 / Accepted: 3 June 2021 / Published online: 7 July 2021

(C) The Author(s) 2021

\begin{abstract}
The liver is an important immunological site that can promote immune tolerance or activation. Natural killer (NK) cells are a major immune subset within the liver, and therefore understanding their role in liver homeostasis and inflammation is crucial. Due to their cytotoxic function, NK cells are important in the immune response against hepatotropic viral infections but are also involved in the inflammatory processes of autoimmune liver diseases and fatty liver disease. Whether NK cells primarily promote pro-inflammatory or tolerogenic responses is not known for many liver diseases. Understanding the involvement of NK cells in liver inflammation will be crucial in effective treatment and future immunotherapeutic targeting of NK cells in these disease settings. Here, we explore the role that NK cells play in inflammation of the liver in the context of viral infection, autoimmunity and fatty liver disease.
\end{abstract}

Keywords Liver inflammation $\cdot$ NK cells $\cdot$ Viral hepatitis $\cdot$ Autoimmune liver disease $\cdot$ Fatty liver disease

\section{Introduction}

The liver is a central organ involved in digestion, metabolism and detoxification of blood. The majority of blood entering the liver comes via the hepatic portal vein from the spleen and gastrointestinal tract. This venous blood carries antigens, which are subsequently exposed to the liver immune repertoire, positioning the liver as an important immunological site for both immune tolerance and activation. Dysregulation of these immunological processes can affect both liver and

A. J. Highton, I. S. Schuster, M. A. Degli-Esposti and M. Altfeld contributed equally to this work.

This article is a contribution to the Special issue on: Mediators of liver inflammation and carcinogenesis - Guest Editors: Johannes Herkel \& Dirk Schmidt-Arras

M. Altfeld

m.altfeld@uke.de

1 Heinrich Pette Institute, Leibniz Institute for Experimental Virology, Hamburg, Germany

2 Experimental and Viral Immunology, Department of Microbiology and Infection and Immunity Program, Monash Biomedicine Discovery Institute, Monash University, Clayton, Victoria, Australia

3 Experimental Immunology, Lions Eye Institute, Perth, Western Australia, Australia

4 Institute for Immunology, University Medical Centre Hamburg-Eppendorf, Hamburg, Germany systemic immune responses. The liver is home to a variety of immune cells including Kupffer cells, MAIT cells, $\gamma \delta \mathrm{T}$ cells, $\alpha \beta$ T cells, B cells, NKT cells, ILCs and NK cells [1]. Among these, NK cells make up $40 \%$ of total lymphocytes in the liver of humans [2], indicating the potential for an important role for NK cells in regulating liver immunity. NK cells are important in early innate immune responses but can also regulate other innate and adaptive immune responses [3] and have been suggested to play an important role in the pathogenesis of several liver diseases, including autoimmune diseases of the liver and hepatotropic viral infections [4]. The involvement of NK cells in hepatocellular carcinoma (HCC) (reviewed in $[5,6]$ ), though important, is beyond the scope of this review and not discussed.

NK cells can both lyse infected or cancerous cells and also produce pro-inflammatory cytokines such as interferon gamma (IFN $\gamma)$. The function of NK cells is tightly regulated via signalling through both activating and inhibitory receptors expressed on their surface. In humans, inhibitory killer Iglike receptors (KIRs) primarily bind to human leukocyte antigen (HLA)-B and HLA-C molecules, while the inhibitory receptor NKG2A binds to HLA-E [7-10] (Fig. 1). The interactions with these inhibitory NK cell receptors ensure that healthy cells expressing HLA class I molecules are not inappropriately targeted by NK cells. Activating receptors such as NKp30, NKp44, NKp46 and NKG2D and activating KIRs are also expressed by NK cells and promote NK cell activation upon binding to their ligands, which include stress molecules 


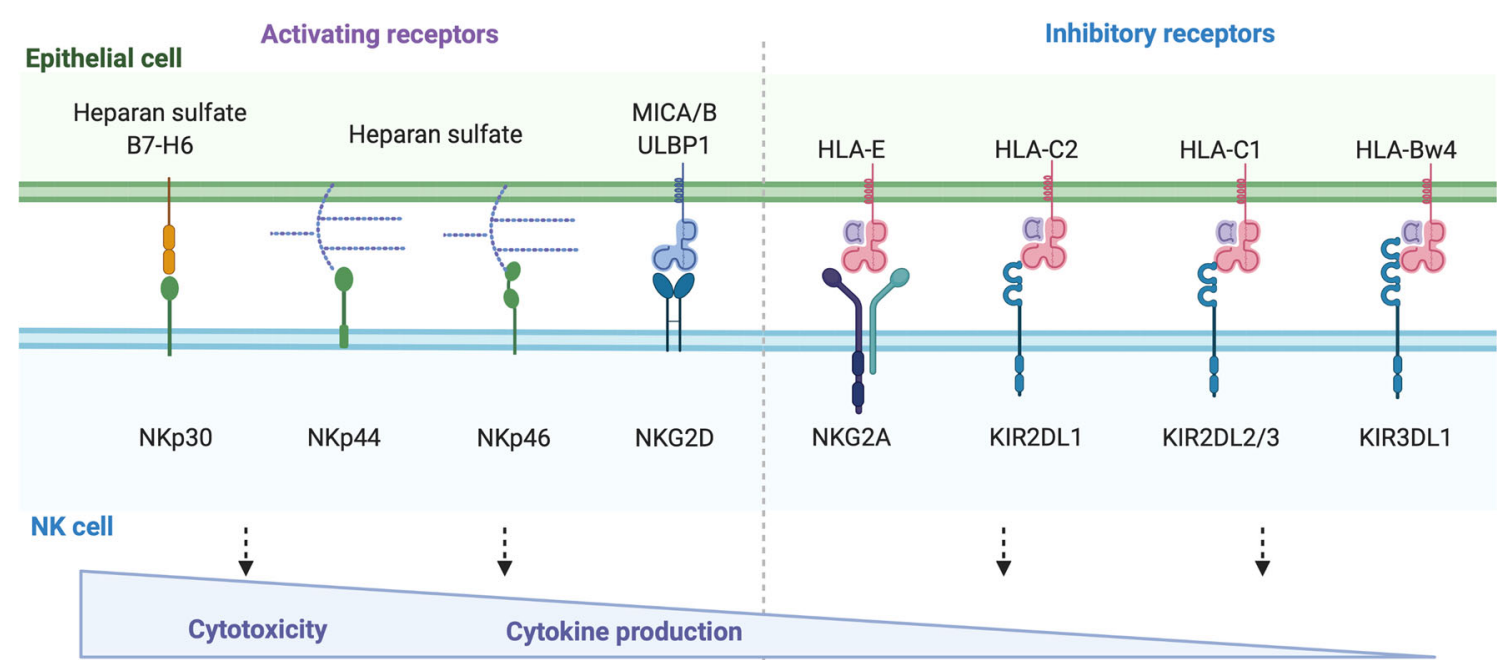

Fig. 1 Activating and inhibitory receptors expressed on NK cells. NK cell-activating receptors binding to their respective ligands promote activation and subsequent cytotoxicity and cytokine production, while inhibitory receptors oppose this response. Created with BioRender.com

and molecules upregulated in response to inflammation [11]. A combination of loss of binding of inhibitory receptors and engagement of activating receptors results in NK cell activation and can facilitate killing of virally infected cells, cancerous cells or inappropriately activated cells.

Tissue-resident populations of NK cells have been described in multiple organs with distinct phenotype and function, indicating specific interactions between these tissues and NK cells [12]. Indeed, the liver possesses a distinct population of liver-resident NK cells (lrNKs) important for the immune function of this organ, along with conventional NK cells (cNKs) (Fig. 2). While cNKs circulate through the liver and vasculature, lrNKs are believed to remain in the liver [13]. cNKs are broadly categorised based on expression of the adhesion molecule CD56 as CD56 $6^{\text {bright }}$ or CD $56^{\text {dim }}$ NK cells, with the latter subset being the most numerous in peripheral blood [14]. In contrast, CD56 ${ }^{\text {bright }} \mathrm{NK}$ cells are largely enriched in the liver compared to the blood, with almost equal frequencies of CD56 $6^{\text {bright }}$ compared to $\mathrm{CD} 56^{\mathrm{dim}} \mathrm{NK}$ cells [15]. These CD56 ${ }^{\text {bright }} 1 \mathrm{NK}$ s can be further defined based on their expression of CD69, CD49a, CCR5 and CXCR6 [13]. CD69 suppresses tissue egress through association with sphingosine-1-phosphate receptor 1, and CD49a is a collagenbinding integrin, thus promoting tissue retention $[16,17]$. The presence of CCL3, CCL5 and CXCL16 in liver sinusoids further promotes the retention of NK cells expressing the cognate receptors CCR5 and CXCR6 [13]. lrNKs have been shown to be not only phenotypically different from their CD56 ${ }^{\text {bright }} \mathrm{cNK}$ brethren but also transcriptionally distinct [18], and as with other tissues [19], these resident NK cells
Fig. 2 Subsets of NK cells present within the liver and vasculature. $\mathrm{CD} 56^{\text {bright }} \mathrm{cNK}$ cells are located primarily within the vasculature. $\mathrm{CD} 56^{\mathrm{dim}} \mathrm{cNK}$ cells can be found within the vasculature and also in the liver parenchyma. Resident within the liver are lrNK cells expressing CCR5, CXCR3, CXCR6, CD69, CD49a and CD56. Created with BioRender.com

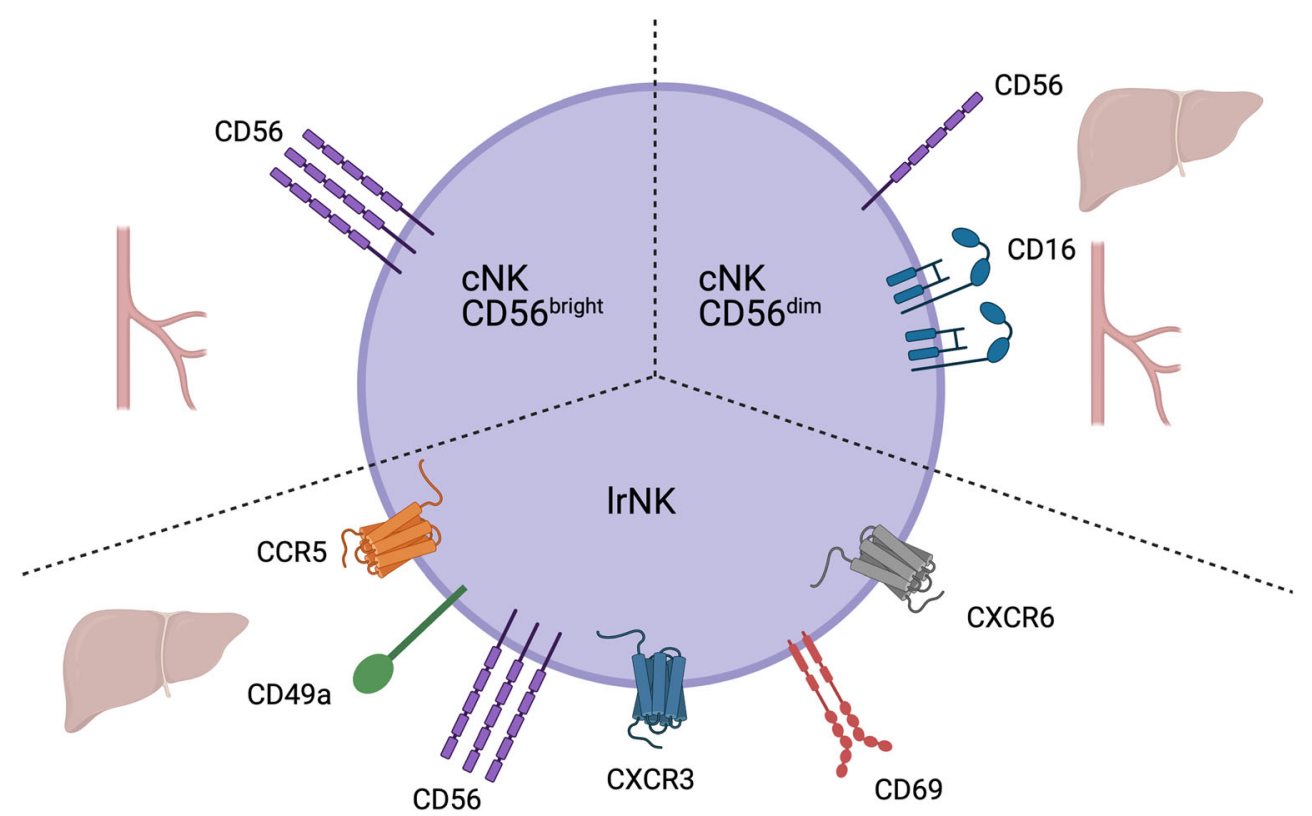


appear to be specifically suited to function in the liver environment and integral to the regulation of immune function in this organ. Here, we discuss liver NK cells and their involvement in the pathogenesis of liver inflammation and diseases following dysregulation.

\section{NK cells in the liver}

Liver-resident NK-like cells $\left(\mathrm{NK} 1.1^{+} \mathrm{CD}^{-}\right)$were first described in the mouse and were initially distinguished from cNK cells by the absence of the mature NK cell marker $\mathrm{CD} 49 \mathrm{~b}$ and high TRAIL expression at steady state [20]. The identification of an increasing number of tissue-resident NKlike cells, not only in the liver but also in other non-lymphoid tissues, led to the introduction of a new nomenclature, which classifies most tissue-resident NK-like cells as innate lymphoid cells type 1 (ILC1) in the mouse (reviewed in Vivier et al. 2018 [21]). Although ILC1s have also been described in humans, NK cells and ILC1s are difficult to distinguish due to the lack of specific markers. For the purpose of this review, we will therefore refer to human liver-resident NK cells and ILC1s as lrNK cells. The transcription factors required for mouse liver ILC1 cell development are distinct from their cNK counterparts: murine ILC1s depend on T-bet and Hobit, while cNK cells require Eomes for their development [22-24]. Liver ILC1s have recently been reported to develop locally, with IFN $\gamma$ production by liver ILC1s promoting their development from IFN $\gamma \mathrm{R}^{+}$liver progenitors [25]. Transfer and parabiosis studies have confirmed that hepatic ILC1s home back to the liver where they are maintained without recirculating, thus identifying them as bona fide tissue-resident cells [26, 27]. Further investigations revealed extensive phenotypic differences between ILC1 and cNK populations [21, 26, 27]. Figure 3 provides an overview of murine liver cNK cells and ILC1s at steady state. Unsupervised dimensional reduction analysis of NKp $46^{+}$cells in the liver (Fig. 3A) shows distinct clustering of ILC1s and cNK cells (Fig. 3B). ILC1s are distinguished as CD49a ${ }^{+}$CD49b cells (Fig. 3C), which lack the expression of Eomes, CD11b, CD62L and KLRG1 but express CD200R, CXCR6, CD69 and CD103, while cNK cells present with the reverse phenotype at steady state (Fig. 3D). Furthermore, unlike cNK cells, ILC1s have limited cytotoxic potential but are capable of mounting a strong cytokine response [21].

Subsequent to the characterisation in the mouse, human $\mathrm{CD} 56^{\text {bright }} \mathrm{CD} 16^{-}$lrNK cells were distinguished from hepatic cNK cells based on the expression of CD69 and the chemokine receptors CXCR6 and CCR5 [13, 18]. Expression of these receptors specifically occurs on lrNK cells, but not on cNK cells, and the chemokine receptors CCR5 and CXCR6 are thought to mediate localisation to liver sinusoids, a compartment rich in the expression of the respective ligands CCL3, CCL5 and CXCL16 [13]. CXCR6 ${ }^{+}$lrNK cells express Eomes but lack T-bet along with a number of KIR molecules [13, 18]. Functionally, $\mathrm{CXCR}^{+}{ }^{+}$lrNK cells produce less IFN $\gamma$, tumour necrosis factor (TNF) and macrophage inflammatory protein (MIP)-1 $\beta$ in response to stimulation than hepatic cNK cells. They also express less perforin and Granzyme B but show enhanced Granzyme K expression and are capable of degranulation [28]. Finally, a study investigating hepatic NK cells in liver transplants ascertained that, although $\mathrm{CXCR}^{+}{ }^{+} \mathrm{rNK}$ cells are long-lived and do not recirculate, they could still be replenished from the circulation [28]. In addition to CXCR6 ${ }^{+}$ CD56 ${ }^{\text {bright }} \mathrm{CD}^{-} 6^{-}$lrNK cells, a second liver-resident NK cell population has been described [29]. These cells are CD56 bright CD16, lack CXCR6 expression and instead are identified by expression of CD49a - similar to mouse ILC1s [26, 29]. $\mathrm{CD}_{49 \mathrm{a}^{+}}$lrNK were present in approximately $40 \%$ of tested individuals with a frequency of approximately $2.3 \%$ of hepatic CD56 ${ }^{\text {bright }}$ cells. CD56 $6^{\text {bright }} \mathrm{CD} 49 \mathrm{a}^{+} \mathrm{NK}$ cells specifically localised to the liver parenchyma and, unlike CXCR $6^{+}$lrNKs, expressed T-bet but not Eomes. They also exhibited a pattern of KIR and NKG2C expression indicative of clonal-like expansion, although they did not express CD57, a marker expressed on differentiated cNK cells. Furthermore, CD56 ${ }^{\text {bright }} \mathrm{CD} 49 \mathrm{a}^{+}$ lrNK cells had reduced capacity to degranulate compared to hepatic CD49a- NK cells but were potent producers of cytokines such as IFN $\gamma$, TNF and GM-CSF.

Overall, there is compelling evidence to support that the liver harbours multiple distinct subsets of resident as well as circulating NK cells at steady state. We are only beginning to understand the roles that these NK cell subsets play in response to immunological challenges, with many questions still unanswered, such as their roles in maintaining liver homeostasis or during hepatic insults. In this regard, the phenotype, function and anatomical localisation of lrNK and hepatic cNK may provide insights about their specific roles in maintaining overall liver health. For instance, it is highly plausible that sinusoidal lrNK cells may play a role in shaping the responsiveness of other sinusoidal cells, such as Kupffer cells. Interestingly, it has been reported that murine liver ILC1s can generate antigen-specific recall responses in a model of contact hypersensitivity $[26,30]$. By extension, human $\mathrm{CD}_{49 \mathrm{a}^{+}}$lrNK cells may therefore represent an analogous memory-like population, as they are characterised by the expression of a receptor repertoire consistent with clonal expansion [29]. However, how tissue-resident cells can induce antigen-specific responses in distal sites remains to be understood. Below, we review the roles of hepatic NK cell populations in liver homeostasis and in the context of different inflammatory settings.

\section{NK cells in liver homeostasis and tolerance}

The liver is continuously exposed to microorganisms, microbial products and food antigens delivered through the portal 
A

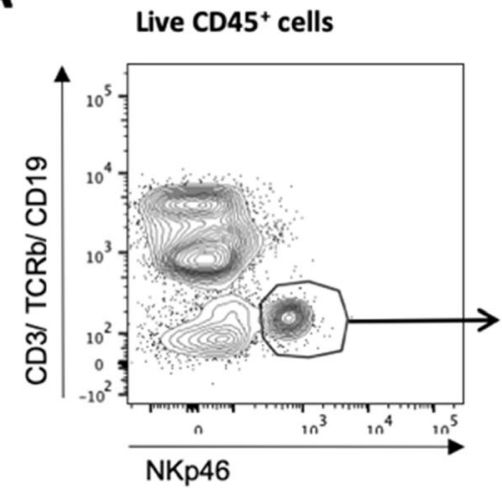

B

$\mathrm{CD} 3 / \mathrm{TCRb} / \mathrm{CD} 19 \cdot \mathrm{NKp}^{+} 6^{+}$cells

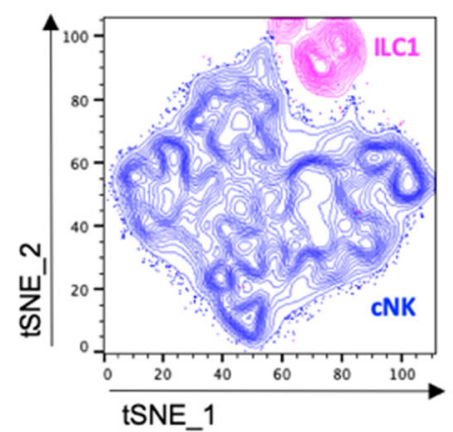

C $_{\text {CD3/TCRb/CD19- NKp46+ cells }}$

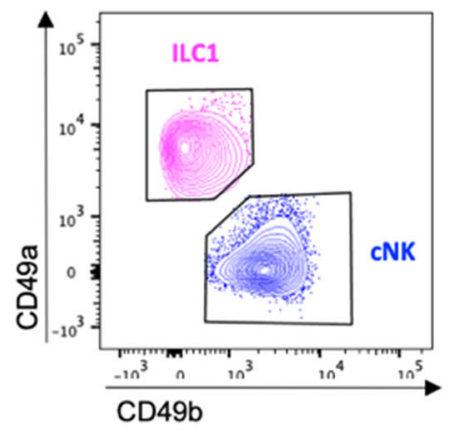

D
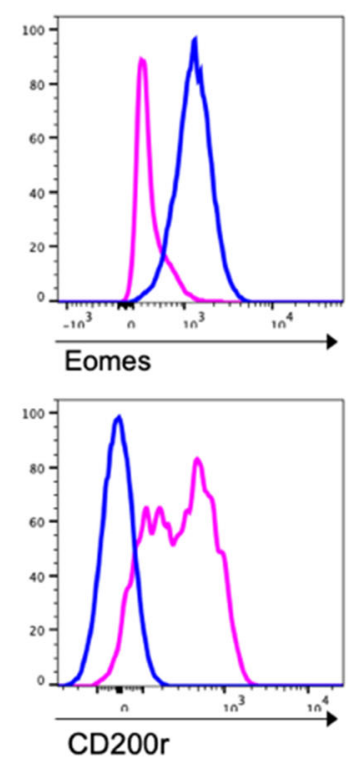

ILC1
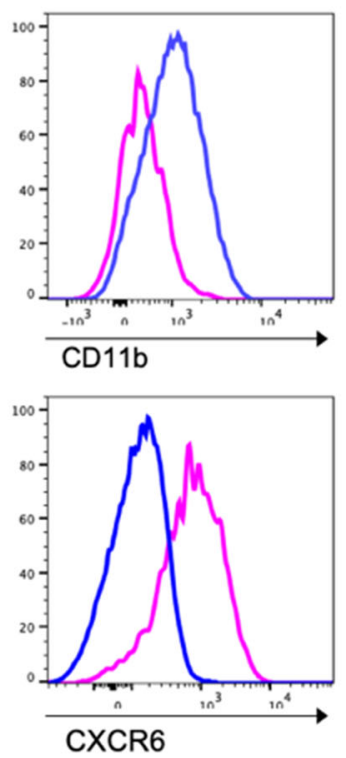

Fig. 3 Distinct phenotypes characterise mouse liver cNK cells and ILC1s at steady state. Liver leukocytes from naïve BALB/c mice were prepared for flow cytometric analysis. A Single live $\mathrm{CD} 45^{+}$cells were gated for CD3- ${ }^{-} \mathrm{TCR} \beta^{-} \mathrm{CD} 19^{-} \mathrm{NKp} 46^{+}$cells, and $\mathbf{B}$ unsupervised nonlinear dimensional reduction using t-distributed stochastic neighbourhood embedding (tSNE) analysis was performed. Distinct clustering of cNK

vein from the intestine. This necessitates an increased level of immune tolerance to avoid excessive inflammation, tissue damage and loss of liver function. This immunological status is mediated by a complex interplay of hepatic cells and immune cells, including NK cells. NK cells can shape, and in turn are shaped, by the hepatic microenvironment via both direct cell-to-cell contact and the production of soluble factors. Kupffer cells are liver sinusoid-resident macrophages that play an important role in activating NK cells via the expression of interleukin (IL)-18 following the detection of microbial products [31]. Simultaneously, Kupffer cells can also suppress NK cell activity through the production of IL-10 that leads to inhibition of IFN $\gamma$ expression and renders NK cells hyporesponsive [31, 32]. In addition, the exposure of hepatic NK cells to apoptotic cells has been shown to induce
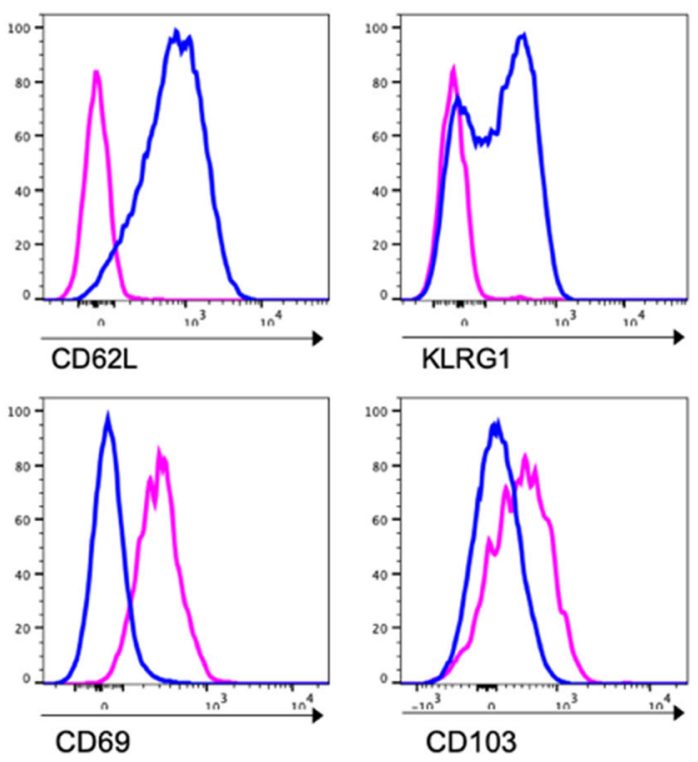

cells (blue population) and ILC1s (pink population) is shown. C Total $\mathrm{NKp} 46^{+}$cells analysed for CD49a and CD49b expression to distinguish ILC1s and cNK cells. D Histogram overlays for the indicated marker expression in ILC1s and cNK cells are shown. Data are concatenated from 3 mice and are representative of 3 independent experiments

transforming growth factor beta (TGF- $\beta$ ) expression by NK cells, which acts in an autocrine manner to reduce NK cell IFN $\gamma$ production [33]. The roles of hepatic lrNK and cNK cell populations in regulating liver homeostasis and tolerance are not well delineated and thus require further investigation to dissect their specific contributions. Transcriptional profile analyses of murine hepatic NK cells and ILC1s revealed increased expression of genes associated with immune regulation in resident ILC1s and an increase in genes associated with cytotoxic function in cNK cells [34]. Consistent with this, hepatic ILC1s are capable of providing protection against acute liver injury [35]. Following the initiation of liver damage, murine ILC1s are activated via IL-12 to produce IFN $\gamma$, which induces the upregulation of the antiapoptotic factor Bcl$\mathrm{xL}$ in hepatocytes. These findings stand in contrast to previous 
reports linking NK cell IFN $\gamma$ production to increased liver damage and impaired regeneration in models of partial hepatectomy with concomitant viral infection or toll-like receptor (TLR) 3 ligand administration [36, 37]. It is important to note that these studies did not dissect the respective roles of lrNK and cNK cells. A possible explanation for the disparate findings on the role of NK cell IFN $\gamma$ production may thus be due to cytokine release by cNK cells in distinct niches within the liver, as well as concentration dependent effects of IFN $\gamma$.

\section{NK cells in a diseased liver}

NK cells can play a role in multiple liver diseases, including autoimmune diseases of the liver, cancer, fatty liver disease and viral diseases. The impact of NK cells on liver diseases is mediated through their direct cytotoxic function against hepatocytes, cholangiocytes or other immune cells in the liver, including $\mathrm{T}$ cells and antigen-presenting cells, and the secretion of cytokines, including IFN $\gamma$ (Fig. 4). NK cells can thereby either promote or reduce liver inflammation. Under normal circumstances, cytotoxic and inflammatory functions of NK cells aid in the clearance of acute disease, thus facilitating a return to homeostasis. However, persistent insults without resolution can lead to chronic liver inflammation due to dysregulation of inflammatory processes. Persistent inflammation can lead to liver fibrosis, which can ultimately progress to cirrhosis and permanent liver damage. Although acute inflammation can be helpful in restoring health, chronic inflammation is a common hallmark of multiple liver diseases
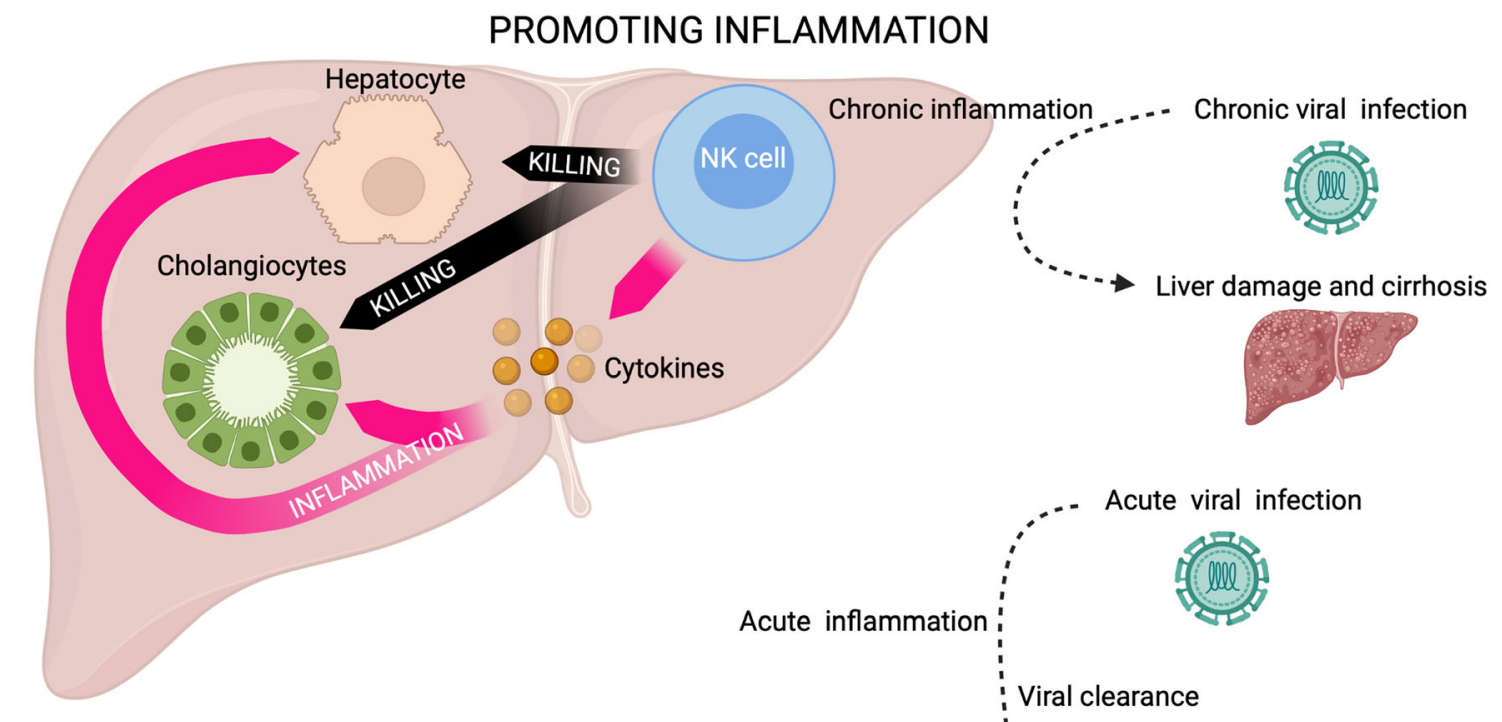

REDUCING INFLAMMATION
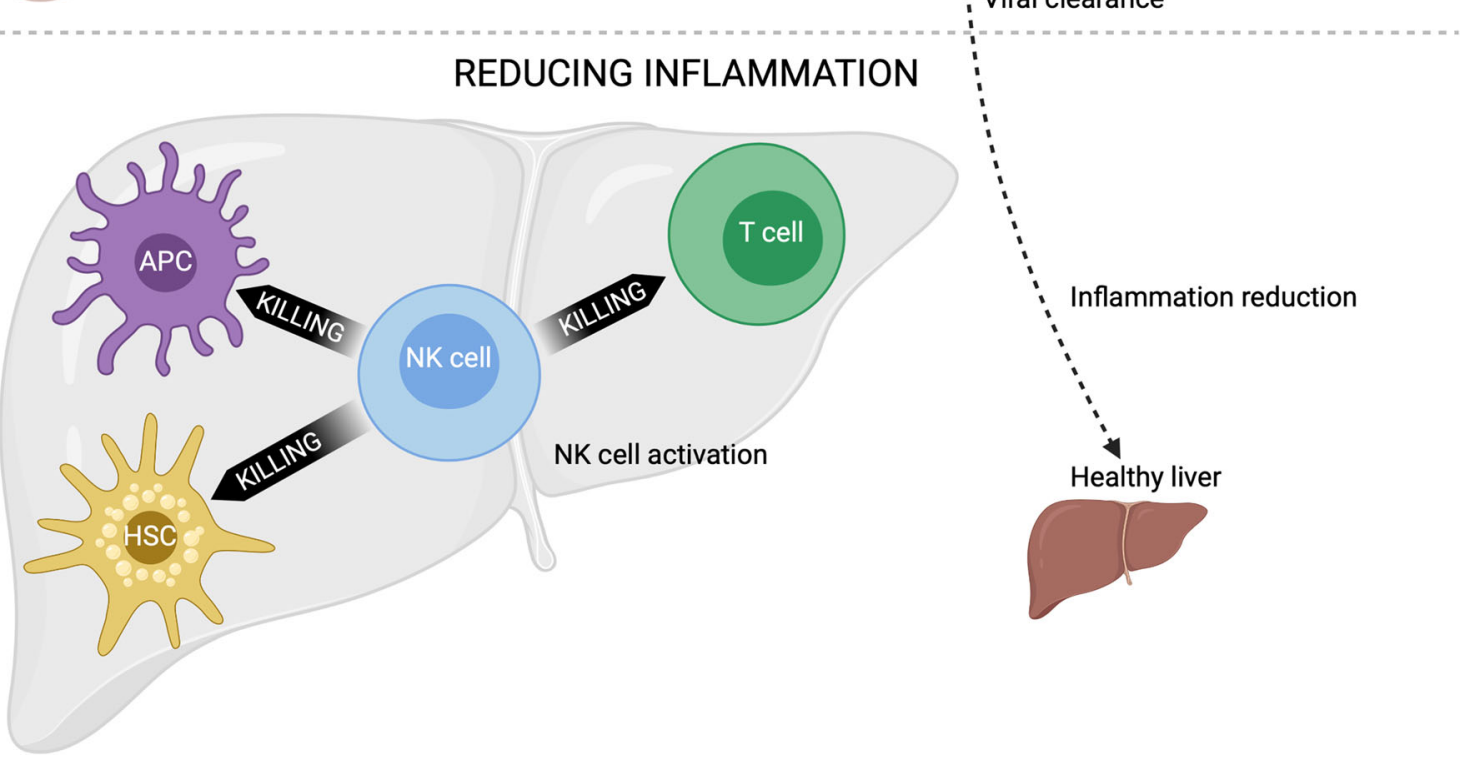

Fig. 4 Potential role of NK cells in promoting and reducing liver inflammation. NK cells can promote liver inflammation through the secretion of pro-inflammatory cytokines and the killing of hepatocytes and cholangiocytes. On the other hand, NK cells can reduce liver inflammation through the killing of activated $\mathrm{T}$ cells and other liverresident cells. Created with BioRender.com 
facilitated by NK cells, along with other immune cells. The role of cNK cells in the aetiology of a number of liver diseases is discussed below.

\section{NK cells in autoimmune liver diseases}

Dysregulation of the liver's immune milieu due to both genetic and environmental factors can lead to autoimmune targeting of liver-specific compartments. Three main autoimmune diseases have been described in the liver: primary biliary cholangitis (PBC), primary sclerosing cholangitis (PSC) and autoimmune hepatitis (AIH) [38].

PBC is most prevalent in women and is typically characterised by destruction of the small intrahepatic bile ducts and production of anti-mitochondrial antibodies [40]. Both circulating and liver NK cell frequencies are increased in $\mathrm{PBC}$ patients, as is the cytotoxic function of NK cells [39, 40], suggesting that NK cells may be involved in $\mathrm{PBC}$ pathogenesis. Indeed, biliary epithelial cells (BECs) have been shown to be destroyed by autologous NK cells at a high NK:BEC ratio [41]. Interestingly, at a low $\mathrm{NK}: \mathrm{BEC}$ ratio, $\mathrm{NK}$ cells protect $\mathrm{BECs}$ from subsequent destruction by NK cells via IFN $\gamma$-mediated upregulation of HLA, though this renders the BECs susceptible to killing by autoreactive T cells [41], again suggesting that NK cells can promote or reduce disease progression depending on the specific circumstances. Circulating NK cells expressing CXCR6 and CD49a are found in higher frequencies in PBC patients compared to healthy controls, and low-dose IL-12 stimulation has been shown to preferentially increase expression of these markers [42], potentially linking monocyte activation to NK cell dysregulation. Together, these data suggest a propensity for liver homing of NK cells in $\mathrm{PBC}$ and a potential role for NK cells in lysing BECs.

PSC occurs equally in both males and females but is more often subclinical in females [43, 44]. PSC is characterised by destruction of both intra- and extra-hepatic bile ducts leading to fibrosis and diffuse inflammation [38]. The frequencies of HLA-Bw4 and HLA-C2, ligands for the inhibitory NK cell receptors KIR3DL1 and KIR2DL1, respectively, were reduced in PSC patients compared to healthy controls, indicating a potential role for NK cells in the disease [45]. PSC patients with less fibrosis were shown to have more hepatic NK cells [46], potentially due to the reported anti-fibrotic role of NK cells in the liver via killing of pro-fibrogenic hepatic stellate cells (HSCs) [47-50]. Increased CCR7 expression has been reported on circulating and intrahepatic NK cells in PSC patients [51], and plasma levels and intrahepatic expression of CCL21, the ligand for CCR7, were increased in PSC patients [51]. Moreover, CCL21 can be produced by CD $11 \mathrm{c}^{+}$cells present in the portal tracts of PSC livers [52]. Overall, these data suggest that the recruitment of CCR7-expressing NK cells may be contributing to liver inflammation in PSC patients.
$\mathrm{AIH}$ is a chronic liver disease that can present as either type I or type II disease [53]. These two disease types can be distinguished based on the presence of circulating autoantibodies. Anti-nuclear antibodies or anti-smooth muscle antibodies define type I disease, and anti-liver kidney microsomal type-1 or anti-liver cytosol type-1 autoantibodies define type II disease [54-57]. Type I is the most common form of the disease and occurs predominantly in females, while type II is more frequent in girls between the ages of 2 and 14 [56, 58]. In a Japanese cohort, KIR3DL1 and the cognate ligand HLA-B Bw4-80Ile were associated with AIH, while KIR3DL1/HLA-B Bw4-80Thr and KIR2DL1/HLC-C2 were associated with protection from the disease [59]. In a separate study, KIR2DS1 and HLA-C2 were associated with AIH [60]. These associations between KIR/HLA compound genotypes and AIH suggest a potential role for $\mathrm{KIR}^{+} \mathrm{NK}$ cells in AIH pathogenesis. Furthermore, a recent study showed that a SNP in the HLA-DP beta chain is associated with the risk of developing AIH [61]. Interestingly, this susceptibility SNP tracks a subset of HLA-DP molecules that serve as ligands for the activating NK cell receptor NKp44 [62], further supporting a role of NK cells in AIH pathogenesis. PolyI:C treatment in a mouse model of hepatitis demonstrated recruitment and activation of NK cells in the liver with partial disease abrogation following NK cell depletion [63]. The frequency of circulating CD56 $6^{\text {bright }} \mathrm{NK}$ cells was found to be increased in untreated AIH patients prior to corticosteroid treatment [64], whereas decreased frequencies of circulating CD56 ${ }^{\mathrm{dim}} \mathrm{NK}$ cells have been observed in patients with active AIH or while in remission [65]. Interestingly, in a mouse model of AIH, CXCR3 ${ }^{+}$ NK cells, similar to human CD56 ${ }^{\mathrm{dim}} \mathrm{NK}$ cells, were enriched in the liver, though both circulating and hepatic NK cells had increased cytotoxic phenotypes [65]. These data further suggest an important role for NK cells in AIH, including possible recruitment of destructive NK cells from the periphery. However, lrNK cells might also modulate the function of antigen-presenting cells or $\mathrm{T}$ cells in the liver and thereby reduce liver inflammation in AIH (Fig. 4). Overall, further research is required to understand the precise role of lrNK cells, and particular subpopulations of lrNK cells, in the pathogenesis of autoimmune liver diseases.

\section{Viral infections of the liver}

A number of viruses infect the liver; however, the most prevalent are the hepatotropic hepatitis viruses. There are 5 types of hepatitis viruses, classified as Hepatitis A to E despite these viruses being unrelated to each other [66]. Hepatitis A (HAV) and $\mathrm{E}$ (HEV) cause only acute infection, while hepatitis B (HBV), C (HCV) and D (HDV) can establish long-lasting chronic infections. In addition, chronic HBV and HCV infection can lead to the development of life-threatening liver 
diseases, such as cirrhosis and HCC. Although vaccines are available for HAV, HBV and HDV, and HCV is treatable by direct acting anti-virals (DAA), these viral infections continue to cause considerable morbidity and mortality and carry a significant burden of disease globally [67].

In patients with acute HBV infection, NK cells are highly activated as characterised by elevated expression of activating receptors, reduced expression of inhibitory receptors, increased IFN $\gamma$ expression and enhanced ability to degranulate compared to NK cells from healthy controls [68, 69]. Importantly, this increased activation state was shown to correlate with the severity of liver damage (likely promoted by the cytolytic capacity of NK cells) as well as improved HBV control (likely via IFN $\gamma$ production by NK cells) [68]. A more recent study outlined a role for activation of antibody-dependent cellular cytotoxicity (ADCC) by NK cells in responses to acute HBV infection and the generation of both cytotoxic and cytokine responses [70]. In addition to acting as direct effectors, NK cells can promote adaptive responses in a mouse model of acute HBV infection [71]. IFN $\gamma$ production by hepatic CD49a

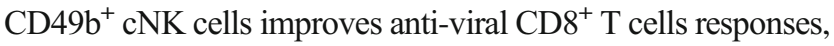
leading to enhanced viral clearance [71]. By contrast, during chronic HBV (CHB) infection, NK cells display fewer activating and more inhibitory receptors and lose effector functions, particularly the capacity to secrete cytokines [72, 73]. These findings are consistent with recent studies describing the expansion of dysfunctional CD56 $6^{-} \mathrm{CD} 16^{+} \mathrm{NK}$ cells and a transcriptional NK cell profile similar to that of exhausted $\mathrm{T}$ cells in CHB patients [74, 76]. NK cell dysfunction in CHB patients is mediated by elevated expression of immunosuppressive cytokines such as IL-10 and TGF- $\beta[75,76]$. Blocking these cytokines increased the expression of activating receptors and improved NK cell effector function. Although CHB significantly decreases the functionality of NK cells, numerous studies have reported increased TRAIL expression on both circulating and hepatic NK cells [77-79]. CD56 ${ }^{\text {bright }}$ TRAIL $^{+} \mathrm{NK}$ cells can kill hepatocytes in vitro, and their presence has been associated with the severity of liver damage in patients with CHB-related liver cirrhosis $[77,78]$. Furthermore, $\mathrm{TRAIL}^{+} \mathrm{NK}$ cells have been shown to induce apoptosis of $\mathrm{HBV}$-specific $\mathrm{CD}^{+} \mathrm{T}$ cells, which would thereby lead to impaired virus control and increased immunopathology. Thus, $\mathrm{TRAIL}^{+} \mathrm{NK}$ cells can mediate both liver damage (by killing hepatocytes) and impair antiviral responses (by killing anti-viral T cells) [79].

Similar to HBV, NK cells are involved in the response to $\mathrm{HCV}$ infection. Although the availability of DAAs has significantly improved the outcome of HCV infection, HCVinduced pathologies still pose a major health burden [67], and understanding the role of the immune response to $\mathrm{HCV}$ remains highly relevant. Genetic analyses have provided evidence for associations between the expression of specific KIRs and their HLA ligands and the outcome of HVC infection. This is best exemplified by the finding that the
KIR2DL3/HLA-C1/C1 genotype is associated with spontaneous resolution of $\mathrm{HCV}$ infection [80]. Furthermore, in culture systems, KIR3DS1 ${ }^{+} \mathrm{NK}$ cells have been shown to recognise and lyse $\mathrm{HCV}$-infected hepatocytes expressing HLA-F and have therefore been postulated to assist in controlling $\mathrm{HCV}$ infection [81]. The role of NK cells during acute HCV infection is clear, but the relevant mechanisms remain largely unknown. Although NK cells from infected subjects have been reported to have an enhanced capacity to secrete IFN $\gamma$ and degranulate compared to those from uninfected controls, these activities do not appear to correlate with the outcome of infection [82]. Interestingly, a recent study has shown that NK cells activated by cytokines present during $\mathrm{HCV}$ infection can kill $\mathrm{CD}^{+} \mathrm{T}$ cells and has proposed that this may actually promote progression to chronicity [83]. In patients with chronic HCV (CHC) infection, the distribution of NK cell subsets is altered, and there is a relative increase in $\mathrm{CD} 56^{\text {bright }} \mathrm{NK}$ cells compared with healthy controls [84, 85]. Furthermore, NK cells display both phenotypic and functional changes. Despite some inconsistencies between different studies, increased expression of activating receptors, such as NKG2D and NKp44, has been reported in NK cells from CHC patients compared to those from healthy controls $[73,86]$. A polarisation in NK cell functionality, manifesting as reduced capacity to express IFN $\gamma$ and TNF but increased degranulation, indicative of greater cytotoxic potential, was noted in CHC patients [86]. This phenotype was attributed to exposure to IFN $\alpha$ as recapitulated by exposing NK cells to this cytokine in vitro [86]. In separate studies, CHC infection was associated with a decrease in NK cell effector function, a phenotype linked to increased expression of the inhibitory receptor CD94/NKG2A [87, 88]. NK cells from CHC patients exhibited higher CD94/NKG2A expression and produced elevated levels of IL-10 and TGF- $\beta$ when cultured with hepatocytes expressing HLA-E, the CD94/NKG2A cognate ligand [87]. Blocking NKG2A signalling resulted in reduced IL-10 and TGF- $\beta$ production by NK cells and restored the ability of $\mathrm{NK}$ cells to participate in the activation of $\mathrm{DC}$ required to prime anti-viral $\mathrm{T}$ cell responses [87]. A more recent study, using a humanised mouse model, confirmed that impaired NK cell function contributes to $\mathrm{HCV}$ persistence and that blocking NKG2A signalling can revive NK cell IFN $\gamma$ secretion and improve NK cell cytotoxicity [88]. This increase in IFN $\gamma$ production led to improved anti-viral $\mathrm{CD}^{+} \mathrm{T}$ cell responses and reduced HCV loads. Importantly, chronic HCV infection appears to permanently affect the functionality of NK cells, as the NK cell repertoire remained altered even after successful DAA treatment [89]. How this may affect NK cell responses to other immunological challenges is unknown. The respective roles of lrNK versus circulating NK cells in the response to $\mathrm{CHC}$ infection are not well understood. Some insight has been provided by a recent study reporting that $\mathrm{CHC}$ patients with lower liver disease scores showed an expansion of 
hepatic $\mathrm{CD} 56^{\text {bright }} \mathrm{CD} 16^{-} \mathrm{NK}$ cells, a population thought to be resident in the liver $[28,90]$. Expansion of $\mathrm{CD} 56^{\text {bright }} \mathrm{CD} 16^{-}$ lrNK cells also correlated with increased levels of IL-10 in portal vein blood and reduced responsiveness of hepatic lymphocytes to TLR stimulation, compared to circulating lymphocytes [90]. These findings suggest that lrNK cells may be involved in maintaining liver homeostasis in CHC. Overall, it is evident that NK cells play an important role in the immune response to both acute and chronic HBV and HCV infection. Activated NK cells can participate in elimination of virally infected cells and regulation of anti-viral responses, as well as maintenance of liver homeostasis, particularly in the acute stages of infection. Thus, dysregulated NK cell responses are often characterised by diminished effector responses and an inhibitory phenotype allowing for viral persistence and enhance tissue damage. Further studies are required to determine not only which type of NK cell responses are required for optimal viral control at different stages of infection but also the distinct roles that tissue-resident and circulating NK cells play in these processes.

In some instances, viral hepatitis can be caused by members of the herpesviridae family, such as cytomegalovirus (CMV) [91]. Although CMV hepatitis is rare in immunocompetent hosts, the virus can cause severe disease in immunocompromised individuals. Acute CMV infection is usually controlled without causing disease, but the virus remains lifelong in a state of latency, and intermittent CMV reactivation occurs but is controlled by the immune system [91]. Immune responses to CMV have been widely studied using mouse models of infection with murine CMV (MCMV). These models have provided extensive insight into the role of NK cells in the immune response to MCMV infection in the liver. Following acute infection, NK cells are recruited into the liver where they contribute to the control of MCMV through cytotoxic and cytokine (mainly IFN $\gamma$ ) responses $[92,93]$. During infection, NK cells also play a critical role in regulating macrophage activation in a perforin-dependent manner [94]. In the absence of NK cell-mediated regulation, excessive TNF production by macrophages leads to severe liver damage [94]. During acute MCMV infection, NK cells in the liver also produce IL-10 [95]. Although this cytokine does not contribute to viral control or the initiation of adaptive anti-viral immunity, it limits the magnitude of CD8 T cell responses and consequent pathology in mice lacking perforin [96]. In humans, expansion of $\mathrm{CD} 56^{\mathrm{dim}} \mathrm{CD} 16^{+} \mathrm{NK}$ cells expressing NKG2C has been noted in individuals with active CMV infection [97, 98]; these cells are maintained long term and can expand following exposure to CMV antigen, as noted in allogeneic stem cell transplantation [99]. The role of these NK cells, referred to as "adaptive or memory-like" NK cells, remains largely unknown, and further investigation is required to determine how memory-like NK cells affect CMV infection and reactivation in organs like the liver.
Severe acute respiratory syndrome coronavirus 2 (SARS$\mathrm{CoV}-2$ ) is the recently emerged virus at the centre of a global pandemic. SARS-CoV-2 infection primarily targets cells of the respiratory tract but virus has been detected in multiple organs, including the liver [100]. Furthermore, SARS-CoV-2 infection can have a series of extrapulmonary manifestations, including hepatobiliary damage (reviewed in [101]). Acute hepatitis has been reported [102, 103], and increased concentrations of enzymes associated with liver damage (AST, ALT) were found to correlate with the severity of COVID-19 disease [103-105]. COVID-19-associated complications have also been reported in a liver transplant patient, where infection appeared related to the virus being passed by a SARS-CoV-2-positive donor [106]. Enormous efforts have been directed to unravel the complexities of protective versus pathogenic immune responses in the context of SARS-CoV-2 infection. However, current understanding of tissue-specific immunity in tissues such as the liver is still limited. Although tissue inflammation and increased frequencies of immune cells have been observed in livers of COVID patients, the potential contribution of $1 \mathrm{rNK}$ or $\mathrm{cNK}$ cells to SARS-CoV-2 control and/or COVID-19 pathology remains unknown [107]. Analyses of circulating NK cells have revealed a reduction in both $\mathrm{CD} 56^{\text {bright }}$ and $\mathrm{CD} 56^{\mathrm{dim}} \mathrm{NK}$ cells in COVID-19 patients compared to healthy controls [108]. The remaining NK cells displayed a more activated phenotype but also appeared to upregulate markers associated with limiting NK cell function (NKG2A), and indeed NK cell effector functions were compromised in severely ill COVID-19 patients [108-110]. Interestingly, an enrichment of "adaptive" NK cells was also observed [108]. A reduction in circulating NK cells has also been reported in children infected by SARS-CoV-2 prompting investigators to suggest that NK cells might have been recruited to sites of infection to provide protective immunity [111]. Overall, NK cells clearly mount a response to SARS-CoV-2 infection, but similar to hepatitis virus infections, they might become dysfunctional during severe disease, and their role in organs like the liver requires further investigation.

In sum, the available evidence demonstrates that during viral infections, populations of NK cells that reside in or are recruited to the liver mediate a plethora of activities. These activities range from those that clearly favour health by providing either anti-viral protective immunity or limiting overt inflammation, to those that are highly pathogenic and contribute to tissue disruption, either directly or by favouring the pathological activities of other cell types. For these reasons, it is imperative to define the role of NK cells in viral infections so that appropriate interventions can be utilised.

\section{Fatty liver disease}

Non-alcoholic fatty liver disease (NAFLD) is the most common chronic liver disease and is characterised by steatosis, the 
accumulation of lipids, within hepatocytes. Progression of the disease can lead to non-alcoholic steatohepatitis (NASH) involving inflammation and fibrosis. Risk of liver cirrhosis and progression to $\mathrm{HCC}$ is increased following transition to NASH. Additionally, NAFLD is often associated with metabolic syndrome along with obesity, high blood pressure and type II diabetes. NAFLD can be controlled early through weight loss and lifestyle changes, but no other treatment is currently available, and the associated co-morbidities complicate treatment if disease progresses further to HCC. Alarmingly, as obesity increases in western nations, so does the frequency of NAFLD and NASH. Evidence from murine models of liver disease have implicated NK cells in disease progression to NASH. In these models, NK cell ligand expression is increased in the liver, thus promoting accumulation of NK cells [112, 113]. IL-15-based activation of NK cells has been shown to lead to NASH in the murine setting [114], but interestingly, NK cells have also been shown to prevent liver fibrosis $[50,115]$. This is achieved both through NK cell influence on macrophage polarisation in the liver in an NKp46dependent manner and via killing of HSCs by NK cells in an NKG2D-dependent manner [50, 115]. In humans, NKp46based protection against fibrosis has also been described, though in the setting of HCV [116]. Increased expression of the activating receptor NKG2D by circulating NK cells has been observed in NASH patients [117], and it is possible that this results in increased HSC killing as seen in the mouse model. Diedrich et al observed a negative correlation between fibrosis and NK cell frequency in the liver, indicating an involvement of NK cells in preventing fibrosis [118].
Interestingly, lower NKG2D expression was observed in circulating NK cells of NAFLD patients compared to healthy individuals, and a similar trend was seen in NK cells within the liver [118]. The downregulation of NKG2D in the context of NAFLD may give rise to a more pro-fibrotic NK cell population, thus contributing to worsening liver disease and fibrosis. It is possible that changes such as this are mediated by metabolic changes. Indeed, the function of NK cells has been shown to be reduced in obese patients due to excessive lipid uptake [119]. NK cells are also known to produce IL-22 following activation [58]. In mice, IL-22 has been shown to have an anti-fibrotic effect [120]; however, IL-22 has also been demonstrated to have a pro-fibrogenic role in a chronic HBV model [121], further confusing matters. Altogether, these data indicate that NK cells have a complex role in the pathogenesis of NAFLD. While NK cells appear to have a role in preventing fibrosis, changes in NKG2D-expression by NK cells accompany increasing fibrosis. Furthermore, proinflammatory NK cell signalling may promote NAFLD progression to NASH, and the role of IL-22 in fibrosis is still not fully understood.

\section{NK cell based/targeted therapies for liver disease}

As NK cells play an important role in liver disease, they also have the potential to serve as a therapeutic target for these diseases. Modulation of existing NK cells can be achieved through cytokine stimulation or antibody treatment targeting
A

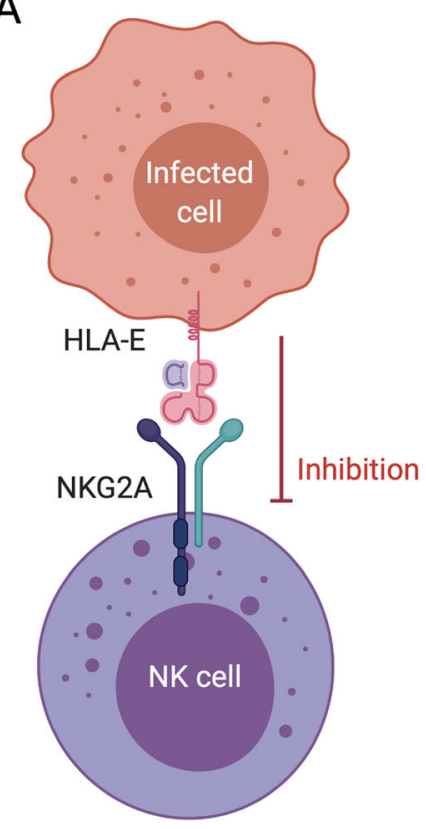

B

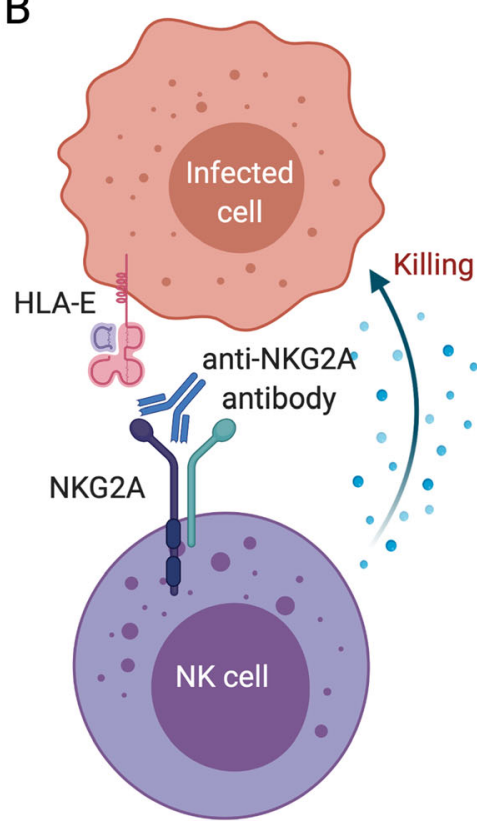

C

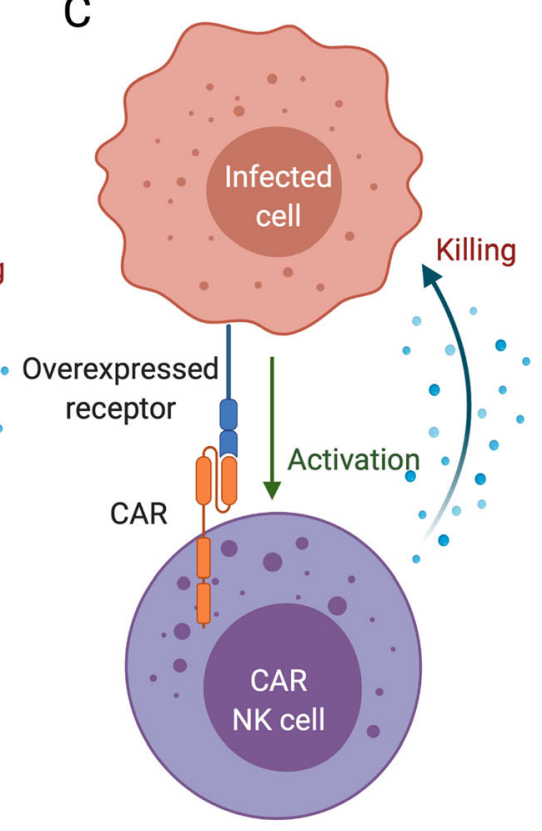

Fig. 5 NK cell targeted therapies. A virally infected cell $\mathbf{A}$ inhibiting an NK cell via signalling through NKG2A or $\mathbf{B}$ being killed due to blockade of inhibition with anti-NKG2A monoclonal antibody. C A CAR NK cell recognising an overexpressed surface protein on an infected cell via an engineered CAR receptor causing activation and subsequent killing. Created with BioRender.com 
either inhibiting or activating NK cell receptors. Indeed, NK cells respond to a wide array of cytokines including type I IFNs, IFN $\gamma$, IL-2, IL-12, IL-15 and IL-18. NK cells from IFN $\alpha$-treated HCV patients have been shown to have increased killing of HSCs in vitro, which has been linked to a reduction in liver fibrosis [49]. IFN $\alpha$ treatment was shown in early studies to reduce fibrosis in HCV patients $[122,123]$ though more recent data indicates that it provides no benefit [124]. Of note, treatment of HCV with direct DAAs shows long-term decrease in liver fibrosis, indicating that viral clearance is sufficient for improvement [125]. Although DAAs now offer effective treatment against $\mathrm{HCV}$, the same is not true for HBV. Treatment with a TLR8 agonist can indirectly activate NK cells via dendritic cell-produced cytokines, and this may prove to be an effective way to combat HBV [126].

Checkpoint blockade has transformed the treatment of melanoma by reversing exhaustion and restoring effective anticancer activity of $\mathrm{T}$ cells. As with $\mathrm{T}$ cells, NK cells also express inhibitory receptors such as KIRs, NKG2A and TIGIT on their cell surface to quell unwanted activation. NK cells expressing inhibitory NKG2A have been shown to be increased in chronic HBV infection [127]. Interestingly, ex vivo blockade of NKG2A increased NK cell cytotoxicity, and blockade in a mouse HBV model improved viral clearance [127]. NKG2A blockade in a mouse HCV model was also shown to improve NK cell cytotoxicity [88]. These results indicate that checkpoint blockade of NK cells may be a viable anti-viral treatment in chronic liver infection (Fig. 5). Blockade of TIGIT [128] and TIM3 [129], inhibitory molecules expressed by NK cells, is known to improve NK cell cytotoxicity against tumours. These molecules are also highly expressed on NK cells in HCV patients with advanced liver fibrosis, indicating that blockade, in this instance, may restore NK cell functionality and protection [130].

Genetically modified NK cells with chimeric antigen receptors (CAR NK cells) targeting HCC are currently being tested in multiple clinical trials, as are bi- and tri-specific antibodies designed to activate NK cells at the same time as targeting them to tumour cells $[131,132]$. CARs are receptors with a specific, often antibody-derived, binding region with downstream signalling domains designed to enhance activation in the context of a specific target ligand [133] (Fig. 5). CAR NK cells and biand tri-specific antibodies all rely on the overexpression of specific ligands on cancerous cells. Whether these technologies can be re-purposed in the context of viral infections or liver fibrosis is yet to be seen and would rely on specific surface expression of otherwise rare ligands on target cells.

\section{Conclusion}

NK cells are present in high abundance in the liver and thus have a large impact on the immune environment in the organ.
They provide potent pro-inflammatory and cytotoxic defence against viral challenge, but dysregulation of the NK-cell response can lead to chronic inflammation and disease. Despite the importance of NK cells in the liver, much is still unknown about the exact mechanisms by which they contribute to different liver diseases, and more study is needed to understand under which circumstances NK cell subpopulations can promote or reduce liver inflammation. Discovery of distinct populations of NK cells within the liver furthermore suggests a heterogeneity in their roles. Better understanding of the specific function of different lrNK cells and cNK cells present in the liver may help to elucidate the importance of these subsets in different disease settings. Indeed, the more is known about the role of NK cells in liver disease, the more opportunity there is for targeted manipulation of these cells to ultimately improve patient outcomes.

Author contribution All authors contributed equally.

Funding Open Access funding enabled and organized by Projekt DEAL. This work was supported by the Deutsche Forschungsgemeinschaft (DFG) through the SFB841.

Availability of data and material N/A.

Code availability N/A.

\section{Declarations}

Conflict of interest The authors declare no competing interests.

Open Access This article is licensed under a Creative Commons Attribution 4.0 International License, which permits use, sharing, adaptation, distribution and reproduction in any medium or format, as long as you give appropriate credit to the original author(s) and the source, provide a link to the Creative Commons licence, and indicate if changes were made. The images or other third party material in this article are included in the article's Creative Commons licence, unless indicated otherwise in a credit line to the material. If material is not included in the article's Creative Commons licence and your intended use is not permitted by statutory regulation or exceeds the permitted use, you will need to obtain permission directly from the copyright holder. To view a copy of this licence, visit http://creativecommons.org/licenses/by/4.0/.

\section{References}

1. Freitas-Lopes M, Mafra K, David B, Carvalho-Gontijo R, Menezes G (2017) Differential location and distribution of hepatic immune cells. Cells 6:48. https://doi.org/10.3390/cells6040048

2. Tanimine N, Tanaka Y, Abe T, Piao J, Chayama K, Ohdan H (2016) Functional behavior of NKp46-positive intrahepatic natural killer cells against hepatitis $\mathrm{C}$ virus reinfection after liver transplantation. Transplantation 100:355-364. https://doi.org/10.1097/ TP.0000000000001031 
3. Lam VC, Lanier LL (2017) NK cells in host responses to viral infections. Curr Opin Immunol 44:43-51. https://doi.org/10.1016/ j.coi.2016.11.003

4. Gao B, Radaeva S, Park O (2009) Liver natural killer and natural killer T cells: immunobiology and emerging roles in liver diseases. J Leukoc Biol 86:513-528. https://doi.org/10.1189/JLB.0309135

5. Liu P, Chen L, Zhang H (2018) Natural killer cells in liver disease and hepatocellular carcinoma and the nk cell-based immunotherapy. J Immunol Res 2018:1-8. https://doi.org/ $10.1155 / 2018 / 1206737$

6. Juengpanich S, Shi L, Iranmanesh Y, Chen J, Cheng Z, Khoo AKJ, Pan L, Wang Y, Cai X (2019) The role of natural killer cells in hepatocellular carcinoma development and treatment: a narrative review. Transl Oncol 12:1092-1107. https://doi.org/10.1016/ j.tranon.2019.04.021

7. Braud VM, Allan DSJ, O'Callaghan CA et al (1998) HLA-E binds to natural killer cell receptors CD94/NKG2A, B and C. Nature 391:795-799. https://doi.org/10.1038/35869

8. Colonna M, Borsellino G, Falco M, Ferrara GB, Strominger JL (1993) HLA-C is the inhibitory ligand that determines dominant resistance to lysis by NK1- and NK2-specific natural killer cells. Proc Natl Acad Sci 90:12000-12004. https://doi.org/10.1073/ pnas.90.24.12000

9. Colonna M, Spies T, Strominger JL, Ciccone E, Moretta A, Moretta L, Pende D, Viale O (1992) Alloantigen recognition by two human natural killer cell clones is associated with HLA-C or a closely linked gene. Proc Natl Acad Sci 89:7983-7985. https:// doi.org/10.1073/pnas.89.17.7983

10. Biassoni R, Falco M, Cambiaggi A, Costa P, Verdiani S, Pende D, Conte R, di Donato C, Parham P, Moretta L (1995) Amino acid substitutions can influence the natural killer (NK)-mediated recognition of HLA-C molecules. Role of serine-77 and lysine- 80 in the target cell protection from lysis mediated by "group 2" or "group 1" NK clones. J Exp Med 182:605-609. https://doi.org/ 10.1084/jem.182.2.605

11. Kumar S (2018) Natural killer cell cytotoxicity and its regulation by inhibitory receptors. Immunology 154:383-393. https://doi. org/10.1111/imm. 12921

12. Peng H, Tian Z (2017) Diversity of tissue-resident NK cells. Semin Immunol 31:3-10. https://doi.org/10.1016/j.smim.2017. 07.006

13. Hudspeth K, Donadon M, Cimino M, Pontarini E, Tentorio P, Preti M, Hong M, Bertoletti A, Bicciato S, Invernizzi P, Lugli E, Torzilli G, Gershwin ME, Mavilio D (2016) Human liver-resident CD56bright/CD16neg NK cells are retained within hepatic sinusoids via the engagement of CCR5 and CXCR6 pathways. J Autoimmun 66:40-50. https://doi.org/10.1016/j.jaut.2015.08.011

14. Cooper MA, Fehniger TA, Caligiuri MA (2001) The biology of human natural killer-cell subsets. Trends Immunol 22:633-640. https://doi.org/10.1016/S1471-4906(01)02060-9

15. Moroso V, Metselaar HJ, Mancham S, Tilanus HW, Eissens D, van der Meer A, van der Laan LJW, Kuipers EJ, Joosten I, Kwekkeboom J (2010) Liver grafts contain a unique subset of natural killer cells that are transferred into the recipient after liver transplantation. Liver Transpl 16:895-908. https://doi.org/10. 1002/lt.22080

16. Bankovich AJ, Shiow LR, Cyster JG (2010) CD69 Suppresses sphingosine 1-phosophate receptor-1 (S1P1) function through interaction with membrane helix 4. J Biol Chem 285:22328-22337. https://doi.org/10.1074/jbc.M110.123299

17. Bank I, Book M, Ware R (1994) Functional role of VLA-1 (CD49A) in adhesion, cation-dependent spreading, and activation of cultured human T lymphocytes. Cell Immunol 156:424-437. https://doi.org/10.1006/cimm.1994.1187

18. Stegmann KA, Robertson F, Hansi N, Gill U, Pallant C, Christophides T, Pallett LJ, Peppa D, Dunn C, Fusai G, Male V,
Davidson BR, Kennedy P, Maini MK (2016) CXCR6 marks a novel subset of T-betloEomeshi natural killer cells residing in human liver. Sci Rep 6:26157. https://doi.org/10.1038/srep26157

19. Dogra P, Rancan C, Ma W, Toth M, Senda T, Carpenter DJ, Kubota M, Matsumoto R, Thapa P, Szabo PA, Li Poon MM, Li J, Arakawa-Hoyt J, Shen Y, Fong L, Lanier LL, Farber DL (2020) Tissue determinants of human nk cell development, function, and residence. Cell 180:749-763.e13. https://doi.org/10.1016/j.cell. 2020.01.022

20. Takeda K, Cretney E, Hayakawa Y, Ota T, Akiba H, Ogasawara K, Yagita H, Kinoshita K, Okumura K, Smyth MJ (2005) TRAIL identifies immature natural killer cells in newborn mice and adult mouse liver. Blood 105:2082-2089. https://doi.org/10.1182/ blood-2004-08-3262

21. Vivier E, Artis D, Colonna M, Diefenbach A, di Santo JP, Eberl G, Koyasu S, Locksley RM, McKenzie ANJ, Mebius RE, Powrie F, Spits H (2018) Innate lymphoid cells: 10 years on. Cell 174:1054 1066. https://doi.org/10.1016/j.cell.2018.07.017

22. Daussy C, Faure F, Mayol K, Viel S, Gasteiger G, Charrier E, Bienvenu J, Henry T, Debien E, Hasan UA, Marvel J, Yoh K, Takahashi S, Prinz I, de Bernard S, Buffat L, Walzer T (2014) Tbet and Eomes instruct the development of two distinct natural killer cell lineages in the liver and in the bone marrow. J Exp Med 211:563-577. https://doi.org/10.1084/jem.20131560

23. Mackay LK, Minnich M, Kragten NAM, Liao Y, Nota B, Seillet C, Zaid A, Man K, Preston S, Freestone D, Braun A, WynneJones E, Behr FM, Stark R, Pellicci DG, Godfrey DI, Belz GT, Pellegrini M, Gebhardt T, Busslinger M, Shi W, Carbone FR, van Lier RAW, Kallies A, van Gisbergen KPJM (2016) Hobit and Blimp1 instruct a universal transcriptional program of tissue residency in lymphocytes. Science (80-) 352:459-463. https://doi.org/ 10.1126/science.aad2035

24. Gordon SM, Chaix J, Rupp LJ, Wu J, Madera S, Sun JC, Lindsten T, Reiner SL (2012) The transcription factors T-bet and Eomes control key checkpoints of natural killer cell maturation. Immunity 36:55-67. https://doi.org/10.1016/j.immuni.2011.11.016

25. Bai L, Vienne M, Tang L, Kerdiles Y, Etiennot M, Escalière B, Galluso J, Wei H, Sun R, Vivier E, Peng H, Tian Z (2021) Liver type 1 innate lymphoid cells develop locally via an interferon- $\gamma-$ dependent loop. Science (80-) 371:eaba4177. https://doi.org/10. 1126/science.aba4177

26. Peng H, Jiang X, Chen Y, Sojka DK, Wei H, Gao X, Sun R, Yokoyama WM, Tian Z (2013) Liver-resident NK cells confer adaptive immunity in skin-contact inflammation. J Clin Invest 123:1444-1456. https://doi.org/10.1172/JCI66381

27. El Weizman O, Adams NM, Schuster IS et al (2017) ILC1 confer early host protection at initial sites of viral infection. Cell 171: 795-808.e12. https://doi.org/10.1016/j.cell.2017.09.052

28. Cuff AO, Robertson FP, Stegmann KA, Pallett LJ, Maini MK, Davidson BR, Male V (2016) Eomes hi NK cells in human liver are long-lived and do not recirculate but can be replenished from the circulation. J Immunol 197:4283-4291. https://doi.org/10. 4049/jimmunol.1601424

29. Marquardt N, Béziat V, Nyström S, et al (2015) Cutting edge: identification and characterization of human intrahepatic CD49a ${ }^{+}$NK Cells. J Immunol 194:2467-2471. https://doi.org/10. 4049/jimmunol.1402756

30. Paust S, Gill HS, Wang B-Z, Flynn MP, Moseman EA, Senman B, Szczepanik M, Telenti A, Askenase PW, Compans RW, von Andrian UH (2010) Critical role for the chemokine receptor CXCR6 in NK cell-mediated antigen-specific memory of haptens and viruses. Nat Immunol 11:1127-1135. https://doi.org/10.1038/ ni. 1953

31. Tu Z, Bozorgzadeh A, Pierce RH, Kurtis J, Crispe IN, Orloff MS (2008) TLR-dependent cross talk between human Kupffer cells 
and NK cells. J Exp Med 205:233-244. https://doi.org/10.1084/ jem.20072195

32. Lassen MG, Lukens JR, Dolina JS, Brown MG, Hahn YS (2010) Intrahepatic IL-10 maintains NKG2A + Ly49 - liver NK cells in a functionally hyporesponsive state. J Immunol 184:2693-2701. https://doi.org/10.4049/jimmunol.0901362

33. Chong WP, Zhou J, Law HKW, Tu W, Lau YL (2010) Natural killer cells become tolerogenic after interaction with apoptotic cells. Eur J Immunol 40:1718-1727. https://doi.org/10.1002/eji. 200939768

34. Zhou J, Peng H, Li K, Qu K, Wang B, Wu Y, Ye L, Dong Z, Wei H, Sun R, Tian Z (2019) Liver-resident NK cells control antiviral activity of hepatic T cells via the PD-1-PD-L1 axis. Immunity 50: 403-417.e4. https://doi.org/10.1016/j.immuni.2018.12.024

35. Nabekura T, Riggan L, Hildreth AD, O'Sullivan TE, Shibuya A (2020) Type 1 innate lymphoid cells protect mice from acute liver injury via interferon- $\gamma$ secretion for upregulating Bcl-xL expression in hepatocytes. Immunity 52:96-108.e9. https://doi.org/10. 1016/j.immuni.2019.11.004

36. Sun R, Gao B (2004) Negative regulation of liver regeneration by innate immunity (natural killer cells/interferon- $\gamma$ ). Gastroenterology 127:1525-1539. https://doi.org/10.1053/j. gastro.2004.08.055

37. Horras CJ, Lamb CL, Mitchell KA (2011) Regulation of hepatocyte fate by interferon- $\gamma$. Cytokine Growth Factor Rev 22:35-43. https://doi.org/10.1016/j.cytogfr.2011.01.001

38. Alizadeh AHM, Shahnazi A, Rasoulzadeh A, Shams E, Mohammadi M, Darabi F, Behdad M (2012) Characteristic findings of primary sclerosing cholangitis on endoscopic retrograde cholangiography: Which is the Most Common Finding? Clin Med Insights Gastroenterol 5:CGast.S7850. https://doi.org/10. 4137/CGast.S7850

39. Chuang YH, Lian ZX, Tsuneyama K et al (2006) Increased killing activity and decreased cytokine production in NK cells in patients with primary biliary cirrhosis. J Autoimmun 26:232-240. https:// doi.org/10.1016/j.jaut.2006.04.001

40. Shimoda S, Harada K, Niiro H et al (2011) Interaction between toll-like receptors and natural killer cells in the destruction of bile ducts in primary biliary cirrhosis. Hepatology 53:1270-1281. https://doi.org/10.1002/hep.24194

41. Shimoda S, Hisamoto S, Harada K, Iwasaka S, Chong Y, Nakamura M, Bekki Y, Yoshizumi T, Shirabe K, Ikegami T, Maehara Y, He XS, Gershwin ME, Akashi K (2015) Natural killer cells regulate $\mathrm{T}$ cell immune responses in primary biliary cirrhosis. Hepatology 62:1817-1827. https://doi.org/10.1002/hep.28122

42. Hydes TJ, Blunt MD, Naftel J, Vallejo AF, Seumois G, Wang A, Vijayanand P, Polak ME, Khakoo SI (2019) Constitutive activation of natural killer cells in primary biliary cholangitis. Front Immunol 10:1-12. https://doi.org/10.3389/fimmu.2019.02633

43. Weismüller TJ, Strassburg CP, Trivedi PJ et al (2017) Patient age, sex, and inflammatory bowel disease phenotype associate with course of primary sclerosing cholangitis. Gastroenterology 152: 1975-1984.e8. https://doi.org/10.1053/j.gastro.2017.02.038

44. Lunder AK, Hov JR, Borthne A, Gleditsch J, Johannesen G, Tveit K, Viktil E, Henriksen M, Hovde Ø, Huppertz-Hauss G, Høie O, Høivik ML, Monstad I, Solberg IC, Jahnsen J, Karlsen TH, Moum B, Vatn M, Negård A (2016) Prevalence of sclerosing cholangitis detected by magnetic resonance cholangiography in patients with long-term inflammatory bowel disease. Gastroenterology 151: 660-669.e4. https://doi.org/10.1053/j.gastro.2016.06.021

45. Karlsen TH, Boberg KM, Olsson M, Sun JY, Senitzer D, Bergquist A, Schrumpf E, Thorsby E, Lie BA (2007) Particular genetic variants of ligands for natural killer cell receptors may contribute to the HLA associated risk of primary sclerosing cholangitis. J Hepatol 46:899-906. https://doi.org/10.1016/j. jhep.2007.01.032
46. Berglin L, Bergquist A, Johansson H, Glaumann H, Jorns C, Lunemann S, Wedemeyer H, Ellis EC, Björkström NK (2014) In situ characterization of intrahepatic non-parenchymal cells in PSC reveals phenotypic patterns associated with disease severity. PLoS One 9:1-11. https://doi.org/10.1371/journal.pone.0105375

47. Melhem A, Muhanna N, Bishara A, Alvarez CE, Ilan Y, Bishara T, Horani A, Nassar M, Friedman SL, Safadi R (2006) Antifibrotic activity of NK cells in experimental liver injury through killing of activated HSC. J Hepatol 45:60-71. https://doi.org/10. 1016/j.jhep.2005.12.025

48. Radaeva S, Sun R, Jaruga B, Nguyen VT, Tian Z, Gao B (2006) Natural killer cells ameliorate liver fibrosis by killing activated stellate cells in NKG2D-dependent and tumor necrosis factorrelated apoptosis-inducing ligand-dependent manners. Gastroenterology 130:435-452. https://doi.org/10.1053/j.gastro. 2005.10.055

49. Glässner A, Eisenhardt M, Krämer B, Körner C, Coenen M, Sauerbruch T, Spengler U, Nattermann J (2012) NK cells from $\mathrm{HCV}$-infected patients effectively induce apoptosis of activated primary human hepatic stellate cells in a TRAIL-, FasL-and NKG2D-dependent manner. Lab Investig 92:967-977. https:// doi.org/10.1038/labinvest.2012.54

50. Gur C, Doron S, Kfir-Erenfeld S, Horwitz E, Abu-tair L, Safadi R, Mandelboim O (2012) NKp46-mediated killing of human and mouse hepatic stellate cells attenuates liver fibrosis. Gut 61:885893. https://doi.org/10.1136/gutjnl-2011-301400

51. Langeneckert AE, Lunemann S, Martrus G, Salzberger W, Hess LU, Ziegler AE, Poch T, Ravichandran G, Matschl U, Bosse JB, Tiegs G, Fischer L, Koch M, Herkel J, Oldhafer KJ, Schramm C, Altfeld M (2019) CCL21-expression and accumulation of CCR7 $+\mathrm{NK}$ cells in livers of patients with primary sclerosing cholangitis. Eur J Immunol 49:758-769. https://doi.org/10.1002/eji. 201847965

52. Grant AJ, Goddard S, Ahmed-Choudhury J, Reynolds G, Jackson DG, Briskin M, Wu L, Hübscher SG, Adams DH (2002) Hepatic expression of secondary lymphoid chemokine (CCL21) promotes the development of portal-associated lymphoid tissue in chronic inflammatory liver disease. Am J Pathol 160:1445-1455. https:// doi.org/10.1016/S0002-9440(10)62570-9

53. Mieli-Vergani G, Vergani D, Czaja AJ, Manns MP, Krawitt EL, Vierling JM, Lohse AW, Montano-Loza AJ (2018) Autoimmune hepatitis. Nat Rev Dis Prim 4:1-22. https://doi.org/10.1038/nrdp. 2018.17

54. Strassburg C, Obermayer-Straub P, Alex B, Durazzo M, Rizzetto M, Tukey RH, Manns MP (1996) Autoantibodies against glucuronosyltransferases differ between viral hepatitis and autoimmune hepatitis. Gastroenterology 111:1576-1586. https://doi. org/10.1016/S0016-5085(96)70020-3

55. Martini E, Abuaf N, Cavalli F, Durand VÉR, Johanet C, Homberg JC (1988) Antibody to liver cytosol (anti-LC1) in patients with autoimmune chronic active hepatitis type 2 . Hepatology 8:16621666. https://doi.org/10.1002/hep.1840080632

56. Homberg J-C, Abuaf N, Bernard O, Islam S, Alvarez F, Khalil SH, Poupon R, Darnis F, Lévy VG, Grippon P, Opolon P, Bernuau J, Benhamou JP, Alagille D (1987) Chronic active hepatitis associated with antiliver/kidney microsome antibody type 1: a second type of "autoimmune" hepatitis. Hepatology 7:13331339. https://doi.org/10.1002/hep.1840070626

57. Johnson G, Holborow E, Glynn L (1965) Antibody to smooth muscle in patients with liver disease. Lancet 286:878-879. https://doi.org/10.1016/S0140-6736(65)92505-5

58. Puustinen L, Barner-Rasmussen N, Pukkala E, Färkkilä M (2019) Incidence, prevalence, and causes of death of patients with autoimmune hepatitis: a nationwide register-based cohort study in Finland. Dig Liver Dis 51:1294-1299. https://doi.org/10.1016/j. dld.2019.01.015 
59. Umemura T, Joshita S, Saito H, Yoshizawa K, Norman GL, Tanaka E, Ota M (2019) KIR/HLA genotypes confer susceptibility and progression in patients with autoimmune hepatitis. JHEP Reports 1:353-360. https://doi.org/10.1016/j.jhepr.2019.09.003

60. Littera R, Chessa L, Onali S, Figorilli F, Lai S, Secci L, la Nasa G, Caocci G, Arras M, Melis M, Cappellini S, Balestrieri C, Serra G, Conti M, Zolfino T, Casale M, Casu S, Pasetto MC, Barca L, Salustro C, Matta L, Scioscia R, Zamboni F, Faa G, Orrù S, Carcassi C (2016) Exploring the role of killer cell immunoglobulin-like receptors and their HLA class I ligands in autoimmune hepatitis. PLoS One 11:2-15. https://doi.org/10. 1371/journal.pone. 0146086

61. Yamazaki T, Umemura T, Joshita S, Yoshizawa K, Tanaka E, Ota M (2018) A cis-eQTL of HLA-DPB1 affects susceptibility to type 1 autoimmune hepatitis. Sci Rep 8:11924. https://doi.org/10.1038/ s41598-018-30406-9

62. Niehrs A, Garcia-Beltran WF, Norman PJ, Watson GM, Hölzemer A, Chapel A, Richert L, Pommerening-Röser A, Körner C, Ozawa M, Martrus G, Rossjohn J, Lee JH, Berry R, Carrington M, Altfeld M (2019) A subset of HLA-DP molecules serve as ligands for the natural cytotoxicity receptor NKp44. Nat Immunol 20:11291137. https://doi.org/10.1038/s41590-019-0448-4

63. Dong Z, Wei H, Sun R, Hu Z, Gao B, Tian Z (2004) Involvement of natural killer cells in PolyI:C-induced liver injury. J Hepatol 41: 966-973. https://doi.org/10.1016/j.jhep.2004.08.021

64. Jeffery HC, Braitch MK, Bagnall C, Hodson J, Jeffery LE, Wawman RE, Wong LL, Birtwistle J, Bartlett H, Lohse AW, Hirschfield GM, Dyson J, Jones D, Hubscher SG, Klenerman P, Adams DH, Oo YH (2018) Changes in natural killer cells and exhausted memory regulatory $\mathrm{T}$ Cells with corticosteroid therapy in acute autoimmune hepatitis. Hepatol Commun 2:421-436. https://doi.org/10.1002/hep4.1163

65. Xiao F, Ai G, Yan W, Wan X, Luo X, Ning Q (2018) Intrahepatic recruitment of cytotoxic NK cells contributes to autoimmune hepatitis progression. Cell Immunol 327:13-20. https://doi.org/10. 1016/j.cellimm.2017.12.008

66. Melnick JL, Howard CR (1994) Classification and taxonomy of hepatitis viruses: summary of a workshop. In: Nishioka K, Suzuki H, Mishiro S, Oda T (eds) Viral Hepatitis and Liver Disease. Springer Japan, Tokyo, pp 47-49

67. WHO (2017) Executive summary - global hepatitis report, 2017. World Heal Organ

68. Zhao J, Li Y, Jin L, Zhang S, Fan R, Sun Y, Zhou C, Shang Q, Li W, Zhang Z, Wang FS (2012) Natural killer cells are characterized by the concomitantly increased interferon- $\gamma$ and cytotoxicity in acute resolved hepatitis B patients. PLoS One 7:e49135. https:// doi.org/10.1371/journal.pone.0049135

69. Fisicaro P, Valdatta C, Boni C, Massari M, Mori C, Zerbini A, Orlandini A, Sacchelli L, Missale G, Ferrari C (2009) Early kinetics of innate and adaptive immune responses during hepatitis $\mathrm{B}$ virus infection. Gut 58:974-982. https://doi.org/10.1136/gut. 2008.163600

70. Yu W-H, Cosgrove C, Berger CT et al (2018) ADCC-mediated CD56dim NK cell responses are associated with early HBsAg clearance in acute HBV infection. Pathog Immun 3:2. https://doi. org/10.20411/pai.v3i1.288

71. Zheng M, Sun R, Wei H, Tian Z (2016) NK cells help induce antihepatitis B virus CD8 + T cell immunity in mice. J Immunol 196: 4122-4131. https://doi.org/10.4049/jimmunol.1500846

72. Lunemann S, Malone DFG, Hengst J, Port K, Grabowski J, Deterding K, Markova A, Bremer B, Schlaphoff V, Cornberg M, Manns MP, Sandberg JK, Ljunggren HG, Björkström NK, Wedemeyer H (2014) Compromised function of natural killer cells in acute and chronic viral hepatitis. J Infect Dis 209:13621373. https://doi.org/10.1093/infdis/jit561
73. Oliviero B, Varchetta S, Paudice E, Michelone G, Zaramella M, Mavilio D, de Filippi F, Bruno S, Mondelli MU (2009) Natural killer cell functional dichotomy in chronic hepatitis B and chronic hepatitis C virus infections. Gastroenterology 137:1151-1160.e7. https://doi.org/10.1053/j.gastro.2009.05.047

74. Wijaya RS, Read SA, Schibeci S, Han S, Azardaryany MK, Poorten D, Lin R, Yuen L, Lam V, Douglas MW, George J, Ahlenstiel G (2021) Expansion of dysfunctional CD56-CD16+ NK cells in chronic hepatitis B patients. Liver Int 41:969-981. https://doi.org/10.1111/liv.14784

75. Peppa D, Micco L, Javaid A, Kennedy PTF, Schurich A, Dunn C, Pallant C, Ellis G, Khanna P, Dusheiko G, Gilson RJ, Maini MK (2010) Blockade of immunosuppressive cytokines restores NK cell antiviral function in chronic hepatitis B virus infection. PLoS Pathog 6:e1001227. https://doi.org/10.1371/journal.ppat. 1001227

76. Sun C, Fu B, Gao Y, Liao X, Sun R, Tian Z, Wei H (2012) TGF$\beta 1$ down-regulation of NKG2D/DAP10 and 2B4/SAP expression on human NK cells contributes to HBV persistence. PLoS Pathog 8:e1002594. https://doi.org/10.1371/journal.ppat.1002594

77. Dunn C, Brunetto M, Reynolds G, Christophides T, Kennedy PT, Lampertico P, Das A, Lopes AR, Borrow P, Williams K, Humphreys E, Afford S, Adams DH, Bertoletti A, Maini MK (2007) Cytokines induced during chronic hepatitis B virus infection promote a pathway for NK cell-mediated liver damage. J Exp Med 204:667-680. https://doi.org/10.1084/jem.20061287

78. Jiang Y, Qin S, Wei X, Liu X, Guan J, Zhu H, Chang G, Chen Y, Lu H, Qian J, Wang Z, Shen M, Lin X (2021) Highly activated TRAIL+ CD56bright NK cells are associated with the liver damage in HBV-LC patients. Immunol Lett 232:9-19. https://doi.org/ 10.1016/j.imlet.2020.12.008

79. Peppa D, Gill US, Reynolds G, Easom NJW, Pallett LJ, Schurich A, Micco L, Nebbia G, Singh HD, Adams DH, Kennedy PTF, Maini MK (2013) Up-regulation of a death receptor renders antiviral T cells susceptible to NK cell-mediated deletion. J Exp Med 210:99-114. https://doi.org/10.1084/jem.20121172

80. Khakoo SI, Thio CL, Martin MP, Brooks CR, Gao X, Astemborski J, Cheng J, Goedert JJ, Vlahov D, Hilgartner M, Cox S, Little AM, Alexander GJ, Cramp ME, O'Brien SJ, Rosenberg WM, Thomas DL, Carrington M (2004) HLA and NK cell inhibitory receptor genes in resolving hepatitis $\mathrm{C}$ virus infection. Science (80-) 305:872-874. https://doi.org/10.1126/ science. 1097670

81. Lunemann S, Schöbel A, Kah J, Fittje P, Hölzemer A, Langeneckert AE, Hess LU, Poch T, Martrus G, Garcia-Beltran WF, Körner C, Ziegler AE, Richert L, Oldhafer KJ, Schulze zur Wiesch J, Schramm C, Dandri M, Herker E, Altfeld M (2018) Interactions between KIR3DS1 and HLA-F activate natural killer cells to control HCV replication in cell culture. Gastroenterology 155:1366-1371.e3. https://doi.org/10.1053/j.gastro.2018.07.019

82. Amadei B, Urbani S, Cazaly A, Fisicaro P, Zerbini A, Ahmed P, Missale G, Ferrari C, Khakoo SI (2010) Activation of natural killer cells during acute infection with hepatitis $\mathrm{C}$ virus. Gastroenterology 138:1536-1545. https://doi.org/10.1053/j. gastro.2010.01.006

83. Hengst J, Klein AL, Lunemann S, Deterding K, Hardtke S, Falk CS, Manns MP, Cornberg M, Schlaphoff V, Wedemeyer H (2018) Role of soluble inflammatory mediators and different immune cell populations in early control of symptomatic acute hepatitis $\mathrm{C}$ virus infection. J Viral Hepat 26:jvh.13050. https://doi.org/10.1111/jvh. 13050

84. Alter G, Jost S, Rihn S, Reyor LL, Nolan BE, Ghebremichael M, Bosch R, Altfeld M, Lauer GM (2011) Reduced frequencies of NKp30+NKp46+, CD161+, and NKG2D+ NK cells in acute $\mathrm{HCV}$ infection may predict viral clearance. J Hepatol 55:278288. https://doi.org/10.1016/j.jhep.2010.11.030 
85. Golden-Mason L, Madrigal-Estebas L, McGrath E, Conroy MJ, Ryan EJ, Hegarty JE, O'Farrelly C, Doherty DG (2008) Altered natural killer cell subset distributions in resolved and persistent hepatitis $\mathrm{C}$ virus infection following single source exposure. Gut 57:1121-1128. https://doi.org/10.1136/gut.2007.130963

86. Ahlenstiel G, Titerence RH, Koh C, Edlich B, Feld JJ, Rotman Y, Ghany MG, Hoofnagle JH, Liang TJ, Heller T, Rehermann B (2010) Natural killer cells are polarized toward cytotoxicity in chronic hepatitis $\mathrm{C}$ in an interferon-alfa-dependent manner. Gastroenterology 138:325-335.e2. https://doi.org/10.1053/j. gastro.2009.08.066

87. Jinushi M, Takehara T, Tatsumi T, Kanto T, Miyagi T, Suzuki T, Kanazawa Y, Hiramatsu N, Hayashi N (2004) Negative regulation of NK cell activities by inhibitory receptor CD94/NKG2A leads to altered nk cell-induced modulation of dendritic cell functions in chronic hepatitis C virus infection. J Immunol 173:6072-6081. https://doi.org/10.4049/jimmunol.173.10.6072

88. Zhang C, Wang X, Li S, Twelkmeyer T, Wang WH, Zhang SY, Wang SF, Chen JZ, Jin X, Wu YZ, Chen XW, Wang SD, Niu JQ, Chen HR, Tang H (2019) NKG2A is a NK cell exhaustion checkpoint for HCV persistence. Nat Commun 10:1507. https://doi.org/ 10.1038/s41467-019-09212-y

89. Strunz B, Hengst J, Deterding K, Manns MP, Cornberg M, Ljunggren HG, Wedemeyer H, Björkström NK (2018) Chronic hepatitis $\mathrm{C}$ virus infection irreversibly impacts human natural killer cell repertoire diversity. Nat Commun 9:2275. https://doi.org/ 10.1038/s41467-018-04685-9

90. Doyle EH, Aloman C, El-Shamy A et al (2021) A subset of liver resident natural killer cells is expanded in hepatitis $\mathrm{C}$-infected patients with better liver function. Sci Rep 11:1551. https://doi. org/10.1038/s41598-020-80819-8

91. Noor A, Panwala A, Forouhar F, Wu GY (2018) Hepatitis caused by herpes viruses: a review. J Dig Dis 19:446-455. https://doi.org/ $10.1111 / 1751-2980.12640$

92. Tay CH, Welsh RM (1997) Distinct organ-dependent mechanisms for the control of murine cytomegalovirus infection by natural killer cells. J Virol 71:267-275. https://doi.org/10.1128/JVI.71.1. 267-275.1997

93. Sumaria N, Dommelen SLH, Andoniou CE, Smyth MJ, Scalzo AA, Degli-Esposti MA (2009) The roles of interferon- $\gamma$ and perforin in antiviral immunity in mice that differ in genetically determined NK-cell-mediated antiviral activity. Immunol Cell Biol 87:559-566. https://doi.org/10.1038/icb.2009.41

94. van Dommelen SLH, Sumaria N, Schreiber RD, Scalzo AA, Smyth MJ, Degli-Esposti MA (2006) Perforin and Granzymes have distinct roles in defensive immunity and immunopathology. Immunity 25:835-848. https://doi.org/10.1016/j.immuni.2006. 09.010

95. Ali AK, Komal AK, Almutairi SM, Lee S-H (2019) Natural killer cell-derived IL-10 prevents liver damage during sustained murine cytomegalovirus infection. Front Immunol 10:1-14. https://doi. org/10.3389/fimmu.2019.02688

96. Lee S-H, Kim K-S, Fodil-Cornu N, Vidal SM, Biron CA (2009) Activating receptors promote NK cell expansion for maintenance, IL-10 production, and CD8 T cell regulation during viral infection. J Exp Med 206:2235-2251. https://doi.org/10.1084/jem. 20082387

97. Lopez-Vergès S, Milush JM, Schwartz BS, et al (2011) Expansion of a unique $\mathrm{CD} 57+\mathrm{NKG} 2 \mathrm{C}$ hi natural killer cell subset during acute human cytomegalovirus infection. Proc Natl Acad Sci USA 108:14725-14732. https://doi.org/10.1073/pnas. 1110900108

98. Gumá M, Angulo A, Vilches C et al (2004) Imprint of human cytomegalovirus infection on the NK cell receptor repertoire. Blood 104: 3664-3671. https://doi.org/10.1182/blood-2004-05-2058
99. Foley B, Cooley S, Verneris MR, Pitt M, Curtsinger J, Luo X, Lopez-Vergès S, Lanier LL, Weisdorf D, Miller JS (2012) Cytomegalovirus reactivation after allogeneic transplantation promotes a lasting increase in educated $\mathrm{NKG} 2 \mathrm{C}+$ natural killer cells with potent function. Blood 119:2665-2674. https://doi.org/10. 1182/blood-2011-10-386995

100. Puelles VG, Lütgehetmann M, Lindenmeyer MT, Sperhake JP, Wong MN, Allweiss L, Chilla S, Heinemann A, Wanner N, Liu S, Braun F, Lu S, Pfefferle S, Schröder AS, Edler C, Gross O, Glatzel M, Wichmann D, Wiech T, Kluge S, Pueschel K, Aepfelbacher M, Huber TB (2020) Multiorgan and renal tropism of SARS-CoV-2. N Engl J Med 383:590-592. https://doi.org/10. 1056/NEJMc2011400

101. Gupta A, Madhavan MV, Sehgal K, Nair N, Mahajan S, Sehrawat TS, Bikdeli B, Ahluwalia N, Ausiello JC, Wan EY, Freedberg DE, Kirtane AJ, Parikh SA, Maurer MS, Nordvig AS, Accili D, Bathon JM, Mohan S, Bauer KA, Leon MB, Krumholz HM, Uriel N, Mehra MR, Elkind MSV, Stone GW, Schwartz A, Ho DD, Bilezikian JP, Landry DW (2020) Extrapulmonary manifestations of COVID-19. Nat Med 26:1017-1032. https://doi.org/10. 1038/s41591-020-0968-3

102. Yao X, Ye F, Zhang M, Cui C, Huang B, Niu P, Liu X, Zhao L, Dong E, Song C, Zhan S, Lu R, Li H, Tan W, Liu D (2020) In vitro antiviral activity and projection of optimized dosing design of hydroxychloroquine for the treatment of severe acute respiratory syndrome coronavirus 2 (SARS-CoV-2). Clin Infect Dis 71:732-739. https://doi.org/10.1093/cid/ciaa237

103. Zhang C, Shi L, Wang F-S (2020) Liver injury in COVID-19: management and challenges. Lancet Gastroenterol Hepatol 5: 428-430. https://doi.org/10.1016/S2468-1253(20)30057-1

104. Huang C, Wang Y, Li X, Ren L, Zhao J, Hu Y, Zhang L, Fan G, Xu J, Gu X, Cheng Z, Yu T, Xia J, Wei Y, Wu W, Xie X, Yin W, Li H, Liu M, Xiao Y, Gao H, Guo L, Xie J, Wang G, Jiang R, Gao Z, Jin Q, Wang J, Cao B (2020) Clinical features of patients infected with 2019 novel coronavirus in Wuhan, China. Lancet 395: 497-506. https://doi.org/10.1016/S0140-6736(20)30183-5

105. Guan W, Ni Z, Hu Y, Liang WH, Ou CQ, He JX, Liu L, Shan H, Lei CL, Hui DSC, du B, Li LJ, Zeng G, Yuen KY, Chen RC, Tang CL, Wang T, Chen PY, Xiang J, Li SY, Wang JL, Liang ZJ, Peng YX, Wei L, Liu Y, Hu YH, Peng P, Wang JM, Liu JY, Chen Z, Li G, Zheng ZJ, Qiu SQ, Luo J, Ye CJ, Zhu SY, Zhong NS, China Medical Treatment Expert Group for Covid-19 (2020) Clinical characteristics of coronavirus disease 2019 in China. N Engl J Med 382:1708-1720. https://doi.org/10.1056/NEJMoa2002032

106. Lagana SM, De Michele S, Lee MJ et al (2020) COVID-19-associated hepatitis complicating recent living donor liver transplantation. Arch Pathol Lab Med 144:929-932. https://doi.org/10.5858/ arpa.2020-0186-SA

107. Wang C, Xu J, Wang S, Pan S, Zhang J, Han Y, Huang M, Wu D, Yang Q, Yang X, Yang Y, Shu T, Zou X, Li R, Luo Y, Yao R, Wang Y, Qiu Y, Wang Y, Zhang DY, Yao Q, Yan Y, Zhou X, Shang Y (2020) Imaging mass cytometric analysis of postmortem tissues reveals dysregulated immune cell and cytokine responses in multiple organs of COVID-19 patients. Front Microbiol 11: 600989. https://doi.org/10.3389/fmicb.2020.600989

108. Maucourant C, Filipovic I, Ponzetta A, Aleman S, Cornillet M, Hertwig L, Strunz B, Lentini A, Reinius B, Brownlie D, Gomez AC, Ask EH, Hull RM, Haroun-Izquierdo A, Schaffer M, Klingström J, Folkesson E, Buggert M, Sandberg JK, Eriksson LI, Rooyackers O, Ljunggren HG, Malmberg KJ, Michaëlsson J, Marquardt N, Hammer Q, Strålin K, Björkström NK, Karolinska COVID-19 Study Group $\$$ (2020) Natural killer cell immunotypes related to COVID-19 disease severity. Sci Immunol 5:eabd6832. https://doi.org/10.1126/sciimmunol.abd6832 
109. Zheng M, Gao Y, Wang G, et al (2020) Functional exhaustion of antiviral lymphocytes in COVID-19 patients. Cell Mol Immunol 17:533-535. https://doi.org/10.1038/s41423-020-0402-2

110. Osman M, Faridi RM, Sligl W, Shabani-Rad MT, DharmaniKhan P, Parker A, Kalra A, Tripathi MB, Storek J, Cohen Tervaert JW, Khan FM (2020) Impaired natural killer cell counts and cytolytic activity in patients with severe COVID-19. Blood Adv 4:5035-5039. https://doi.org/10.1182/bloodadvances. 2020002650

111. Neeland MR, Bannister S, Clifford V, Dohle K, Mulholland K, Sutton P, Curtis N, Steer AC, Burgner DP, Crawford NW, Tosif S, Saffery R (2021) Innate cell profiles during the acute and convalescent phase of SARS-CoV-2 infection in children. Nat Commun 12:1084. https://doi.org/10.1038/s41467-021-21414-x

112. Gomez-Santos L, Luka Z, Wagner C, Fernandez-Alvarez S, Lu SC, Mato JM, Martinez-Chantar ML, Beraza N (2012) Inhibition of natural killer cells protects the liver against acute injury in the absence of glycine N-methyltransferase. Hepatology 56:747-759. https://doi.org/10.1002/hep.25694

113. Kahraman A, Schlattjan M, Kocabayoglu P, Yildiz-Meziletoglu S, Schlensak M, Fingas CD, Wedemeyer I, Marquitan G, Gieseler RK, Baba HA, Gerken G, Canbay A (2010) Major histocompatibility complex class I-related chains A and B (MIC A/B): a novel role in nonalcoholic steatohepatitis. Hepatology 51:92-102. https://doi.org/10.1002/hep.23253

114. Cepero-Donates Y, Lacraz G, Ghobadi F, Rakotoarivelo V, Orkhis S, Mayhue M, Chen YG, Rola-Pleszczynski M, Menendez A, Ilangumaran S, Ramanathan S (2016) Interleukin-15-mediated inflammation promotes non-alcoholic fatty liver disease. Cytokine 82: 102-111. https://doi.org/10.1016/j.cyto.2016.01.020

115. Tosello-Trampont AC, Krueger P, Narayanan S, Landes SG, Leitinger N, Hahn YS (2016) NKp46+ natural killer cells attenuate metabolism-induced hepatic fibrosis by regulating macrophage activation in mice. Hepatology 63:799-812. https://doi. org/10.1002/hep.28389

116. Krämer B, Körner C, Kebschull M, Glässner A, Eisenhardt M, Nischalke HD, Alexander M, Sauerbruch T, Spengler U, Nattermann J (2012) Natural killer p46 High expression defines a natural killer cell subset that is potentially involved in control of hepatitis $\mathrm{C}$ virus replication and modulation of liver fibrosis. Hepatology 56:1201-1213. https://doi.org/10.1002/hep.25804

117. Stiglund N, Strand K, Cornillet M, Stål P, Thorell A, Zimmer CL, Näslund E, Karlgren S, Nilsson H, Mellgren G, Fernø J, Hagström H, Björkström NK (2019) Retained NK cell phenotype and functionality in non-alcoholic fatty liver disease. Front Immunol 10:113. https://doi.org/10.3389/fimmu.2019.01255

118. Diedrich T, Kummer S, Galante A, Drolz A, Schlicker V, Lohse AW, Kluwe J, Eberhard JM, Schulze zur Wiesch J (2020) Characterization of the immune cell landscape of patients with NAFLD. PLoS One 15:1-16. https://doi.org/10.1371/journal. pone. 0230307

119. Michelet X, Dyck L, Hogan A, Loftus RM, Duquette D, Wei K, Beyaz S, Tavakkoli A, Foley C, Donnelly R, O'Farrelly C, Raverdeau M, Vernon A, Pettee W, O'Shea D, Nikolajczyk BS, Mills KHG, Brenner MB, Finlay D, Lynch L (2018) Metabolic reprogramming of natural killer cells in obesity limits antitumor responses. Nat Immunol 19:1330-1340. https://doi.org/10.1038/ s41590-018-0251-7

120. Thakur A, Pedersen LE, Jungersen G (2012) Immune markers and correlates of protection for vaccine induced immune responses. Vaccine 30:4907-4920. https://doi.org/10.1016/j.vaccine.2012. 05.049

121. Zhao J, Zhang Z, Luan Y, Zou Z, Sun Y, Li Y, Jin L, Zhou C, Fu J, Gao B, Fu Y, Wang FS (2014) Pathological functions of interleukin-22 in chronic liver inflammation and fibrosis with hepatitis $\mathrm{B}$ virus infection by promoting $\mathrm{T}$ helper 17 cell recruitment. Hepatology 59:1331-1342. https://doi.org/10.1002/hep. 26916

122. Shiratori Y, Imazeki F, Moriyama M, Yano M, Arakawa Y, Yokosuka O, Kuroki T, Nishiguchi S, Sata M, Yamada G, Fujiyama S, Yoshida H, Omata M (2000) Histologic improvement of fibrosis in patients with hepatitis $\mathrm{C}$ who have sustained response to interferon therapy. Ann Intern Med 132:517-524. https://doi.org/10.7326/0003-4819-132-7-200004040-00002

123. Guerret $\mathrm{S}$, Desmoulière A, Chossegros $\mathrm{P}$, Costa AMA, Badid C, Trépo C, Grimaud JA, Chevallier M (1999) Long-term administration of interferon- $\alpha$ in non-responder patients with chronic hepatitis C: follow-up of liver fibrosis over 5 years. J Viral Hepat 6: 125-133. https://doi.org/10.1046/j.1365-2893.1999.00148.x

124. Di Bisceglie AM, Shiffman ML, Everson GT et al (2008) Prolonged therapy of advanced chronic hepatitis $\mathrm{C}$ with lowdose peginterferon. N Engl J Med 359:2429-2441. https://doi. org/10.1056/nejmoa0707615

125. Laursen TL, Siggaard CB, Kazankov K, Sandahl TD, Møller HJ, Tarp B, Kristensen LH, Laursen AL, Leutscher P, Grønbæk H (2020) Time-dependent improvement of liver inflammation, fibrosis and metabolic liver function after successful direct-acting antiviral therapy of chronic hepatitis C. J Viral Hepat 27:28-35. https://doi.org/10.1111/jvh.13204

126. Jo J, Tan AT, Ussher JE, Sandalova E, Tang XZ, Tan-Garcia A, To N, Hong M, Chia A, Gill US, Kennedy PT, Tan KC, Lee KH, de Libero G, Gehring AJ, Willberg CB, Klenerman P, Bertoletti A (2014) Toll-like receptor 8 agonist and bacteria trigger potent activation of innate immune cells in human liver. PLoS Pathog 10:113. https://doi.org/10.1371/journal.ppat.1004210

127. Wei H, Li F, Wei H et al (2013) Blocking the natural killer cell inhibitory receptor NKG2A increases activity of human natural killer cells and clears hepatitis B virus infection in mice. Gastroenterology 144:392-401. https://doi.org/10.1053/j.gastro. 2012.10.039

128. Zhang Q, Bi J, Zheng X, Chen Y, Wang H, Wu W, Wang Z, Wu Q, Peng H, Wei H, Sun R, Tian Z (2018) Blockade of the checkpoint receptor TIGIT prevents NK cell exhaustion and elicits potent anti-tumor immunity. Nat Immunol 19:723-732. https://doi. org/10.1038/s41590-018-0132-0

129. Xu L, Huang Y, Tan L, Yu W, Chen D, Lu CC, He J, Wu G, Liu $X$, Zhang Y (2015) Increased Tim-3 expression in peripheral NK cells predicts a poorer prognosis and Tim-3 blockade improves NK cell-mediated cytotoxicity in human lung adenocarcinoma. Int Immunopharmacol 29:635-641. https://doi.org/10.1016/j. intimp.2015.09.017

130. Okwor CIA, Oh JS, Crawley AM, Cooper CL, Lee SH (2020) Expression of inhibitory receptors on T and NK cells defines immunological phenotypes of HCV patients with advanced liver fibrosis. iScience 23:101513. https://doi.org/10.1016/j.isci.2020. 101513

131. Felices M, Kodal B, Hinderlie P, Kaminski MF, Cooley S, Weisdorf DJ, Vallera DA, Miller JS, Bachanova V (2019) Novel CD19-targeted TriKE restores NK cell function and proliferative capacity in CLL. Blood Adv 3:897-907. https://doi.org/ 10.1182/bloodadvances.2018029371

132. Albinger N, Hartmann J, Ullrich E (2021) Current status and perspective of CAR-T and CAR-NK cell therapy trials in Germany. Gene Ther. https://doi.org/10.1038/s41434-021-00246-w

133. Pfefferle A, Huntington ND (2020) You have got a fast CAR: chimeric antigen receptor NK cells in cancer therapy. Cancers (Basel) 12:706. https://doi.org/10.3390/cancers12030706

Publisher's note Springer Nature remains neutral with regard to jurisdictional claims in published maps and institutional affiliations. 